\title{
Summary on Adsorption and Photocatalysis for Pollutant Remediation: Mini Review
}

\author{
Buzuayehu Abebe*, H. C. Ananda Murthy, Enyew Amare \\ Department of Applied Chemistry, School of Applied Natural Sciences, Adama Science and Technology University, Adama, \\ Ethiopia \\ Email: `buzea8@gmail.com
}

How to cite this paper: Abebe, B., Murthy, H.C.A. and Amare, E. (2018) Summary on Adsorption and Photocatalysis for Pollutant Remediation: Mini Review. Journal of Encapsulation and Adsorption Sciences, 8, 225-255.

https://doi.org/10.4236/jeas.2018.84012

Received: September 21, 2018

Accepted: December 2, 2018

Published: December 5, 2018

Copyright (c) 2018 by authors and Scientific Research Publishing Inc. This work is licensed under the Creative Commons Attribution International License (CC BY 4.0)

http://creativecommons.org/licenses/by/4.0/

\begin{abstract}
Adsorption and photo catalysis are the most popular methods applied for the reduction of amount of pollutants that enter water bodies. The main challenge in the process of adsorption is the demonstration of the experimental data obtained from sorption processes. For many decades most of the researchers used adsorption and kinetic of adsorption as a repetitive work to describe the adsorption data by using common models such as, Langmuir and Freundlich for adsorption isotherms; PFO and PSO models for kinetics. This has been done without careful evaluation of the characteristics of adsorption process. It has been well understood that adsorption does not degrade the pollutant to eco-friendly products and photo catalysis will not degrade without adsorption of the pollutant on the catalyst. Therefore, understanding the detailed mechanism of adsorption, as well as, photo catalysis has been presented in this paper. During photo catalysis: modification towards suppression of electron-hole recombination, improving visible light response, preventing agglomeration, controlling the shape, size, morphology, etc. are the most important steps. This mini review also widely discusses the key points behind adsorption and photo catalysis.
\end{abstract}

\section{Keywords}

Adsorption, Photo Catalysis, Isotherms, Kinetics, Pollutants

\section{Introduction}

Organic compound and heavy metal pollution presents an important global environmental problem due to its toxic effects that may accumulate in the food chain [1]. These pollutants are found dissolved in water and wastewater in various concentrations. Dyes are identified to be one of the heavy pollutants of water 
bodies, due to the use of large amount of colorings required in clothing, paper products, paints and plastics. Potential hazards brought by heavy metals and several anions in drinking water have raised the concern among the public. Consumption of metal ions and anions usually causes chronic effects, thus humans can suffer from long term exposure to such contaminants without realizing it [2].

Several physical and chemical methods were used to remove dyes and heavy metals from polluted water such as: photo catalysis, coagulation flocculation, adsorption, etc. Among all these methods, adsorption and photo catalysis have been suggested as cheaper and more effective than chemical or physical techniques. These are preferred over other methods because of their relatively simple design, operation, cost effectiveness and energy efficiency [3]. Both methods give crowned achievement towards elimination of organic and inorganic contaminants in addition to the advantages of generating effluents with high quality as well as their simple design. Also the importance of those for water and wastewater treatment is growing in view of the presence of emerging contaminants, such as pharmaceuticals and personal care products (PPCPs), in water bodies.

Several materials were successfully used in processes of discoloration of water pollutants such as clays, composites clay-alginate, polydopamine microspheres, chitosan, activated carbon, metal oxides, etc. [4]. The basic classes of adsorbents include activated carbon, metal oxides, carbon nanotubes, zeolite, clay, mesoporous silica, polymeric resin and metal-organic frameworks, etc. Among those materials modified metal oxides were found to receive wider attention.

In order to reduce the drawbacks behind bare metal oxides during photocatalytic process (such as: fast electron-hole recombination, agglomeration and lack of visible light absorption) [5], different methods, such as: Doping, noble metal deposition, dye sensitization, integrating with equivalent bandgap materials, modification with carbon nanostructures, hydrogenated metal oxides were used. Among those methods researchers choose coupling of two/more semiconductors metal oxides having related band gaps such as: $\mathrm{TiO}_{2} / \mathrm{ZnO}$ [6], $\mathrm{SnO}_{2} / \mathrm{ZnO}$ [7], $\mathrm{SnO}_{2} / \mathrm{ZnO} / \mathrm{TiO}_{2}$ [8], and different including: $\mathrm{ZnO} / \gamma-\mathrm{Mn}_{2} \mathrm{O}_{3}$ [9], $\mathrm{Mn}_{3} \mathrm{O}_{4}-\mathrm{ZnO}$ [10], $\mathrm{ZnO}-\mathrm{MnO}_{2}-\mathrm{Cu}_{2} \mathrm{O}$ [11], $\mathrm{ZnO} / \mathrm{CdS} / \mathrm{Ag}_{2} \mathrm{~S}$ [12], $\mathrm{Ag}_{3} \mathrm{PO}_{4} / \mathrm{ZnFe}_{2} \mathrm{O}_{4} / \mathrm{ZnO}$ [13], $\mathrm{Co}_{3} \mathrm{O}_{4} / \mathrm{ZnO}$ [14], $\mathrm{ZnO} / \mathrm{ZnFe}_{2} \mathrm{O}_{4}$ [15] [16], $\mathrm{ZnO} / \mathrm{Fe}_{2} \mathrm{O}_{3} \& \mathrm{TiO}_{2} / \mathrm{Fe}_{2} \mathrm{O}_{3}$ [17] for preventing the electron-hole recombination and inducing visible light. In addition to this, coupling of bare metal oxide with its doped complements (e.g.: $\mathrm{N}-\mathrm{ZnO}$ coupled $\mathrm{ZnO}$ ) enhances the charge carrier separation, free radical generation and visible light response [18] [19]. However, those modifications are still insufficient towards the satisfactory utilization of solar spectrum, for adequate and complete absorption of visible light, black colored metal oxides synthesized by different techniques (such as: hydrogen-argon (or nitrogen) treatment, plasma enhanced chemical vapor deposition, reduction method assisted by the metals ( $\mathrm{Al}, \mathrm{Zn}$ and $\mathrm{Mg}$ ), electrochemical reduction and anodizing-annealing treatment) are the future approaches towards photacatalysis [20]. 
Among different synthesis methods used to synthesize heterojunction metal oxides, the solution-based approach is the simplest, least energy consuming and easy to control the morphology and sizes of the nanomaterials by controlling the different experimental factors [21]. Approaches used in the synthesis of modified metal oxides includes: impregnation method [22] [23], hydrothermal [24], sol-gel [17] [25], Sono-coprecipitation [26], solvothermal [27], Ultrasonic-microwave [28], etc. As suggested by Osman and Akbulut [29] among these methods, the sol-gel procedure is the most attractive method. Current research has modifying the existing sol-gel procedure by using only water as solvent [25], suggesting that the improved sol-gel method yields a good quality of nanostructure materials with organic solvent free (green synthesis) and lower production cost [30]. In addition studying factors affecting adsorption and photo-degradation such as: catalyst/dosage loading, solution $\mathrm{pH}$, light intensity, light wavelength, temperature [31] and inorganic species $\left(\mathrm{H}_{2} \mathrm{O}_{2}\right.$ [32], $\mathrm{S}_{2} \mathrm{O}_{8}^{2-}$ [33], $\mathrm{BrO}_{3}^{-}$[34], $\mathrm{SO}_{3}^{-}$[32]) should also be taken in to consideration.

This review also wisely discuss and summarizes the detailed mechanism of adsorption and photocatalysis, adsorption isotherms and kinetics, the linear and nonlinear fitness of adsorption, error function, modification of bare metal oxides (minimizing $\mathrm{e}^{-} / \mathrm{h}^{+}$recombination and tuning to the visible light response) towards efficient photacatalysis and conditions/parameters optimization and different analytical techniques.

\section{Adsorption}

Adsorption study comprises of two main aspects; Equilibrium and Kinetic studies. An adsorption isotherm assists to know the adsorption mechanism pathways and the rate of adsorptive uptake which is dependent on the adsorption mechanism. The basis for kinetics study is the kinetic isotherm, which is obtained experimentally by following the adsorbed amount against time. Kinetic investigations develop a model to describe the adsorption rate. Ideally, the model should, with minimal complexity, 1) reveal the rate limiting mechanism and 2) Extrapolate to operating conditions of interest. Accomplishing these two targets should enable one to identify operating conditions with minimal mass transfer resistance and predict adsorbent performance [35].

Many models of varied complexity have been developed to predict the uptake rate and mechanism of adsorption. Among those PFO and PSO models, most commonly used two models in liquid adsorption for kinetic studies. Langmuir Isotherm and Freundlich isotherms were used for controlling the sorption mechanisms for adsorption isotherms [36]. But most of the past works revealed only the uniqueness of those models after well fittings instead of their limitation and strength on different conditions/parameters to explain the physical or chemical adsorption mechanism between adsorbent and adsorbate. Therefore, this review gives direction to use different models for both sorption kinetics and sorption isotherm studies. The appropriates of linear and nonlinear regressions 
and as well as additional error functions other than $R^{2}$ which assists to quantify the error between the model parameters and experimental values were also discussed wisely.

\subsection{Mechanisms of Adsorption}

Adsorption is a surface phenomenon in which adsorptive (gas or liquid) molecules bind to a solid surface. However, in practice, adsorption is performed as an operation, either in batch or continuous mode, in a column packed with porous sorbents. Under such circumstances, mass transfer effects are inevitable. The three common steps includes: Film diffusion (external diffusion), Pore diffusion [intraparticle diffusion (IPD)] and Surface reaction), but, the seven classical steps involved are: 1) Diffusion of the reactants from the bulk phase (boundary layer) to the external surface of the catalyst pellet (film diffusion or interphase diffusion), 2) Diffusion of the reactant from the pore mouth through the catalyst pores to the immediate vicinity of the internal catalytic surface; the point where the chemical transformation occurs, (pore diffusion or intraparticle diffusion), 3) Adsorption of reactants on the inner catalytic surface, 4) Reaction at specific active sites on the catalyst surface, 5) desorption of the products from the inner surface, 6) Diffusion of the products from the interior of the pellet to the pore mouth at the external surface, and 7) Diffusion of the products from the external pellet surface to the bulk fluid (interphase diffusion), are generally used as the key for explanation (Figure 1) [37]. If external transport is greater than internal transport, rate is governed by particle diffusion. If external transport is less than internal transport, rate is governed by film diffusion and if external transport approximately equal to internal transport, the transport of adsorbate ions to the boundary may not be possible at a significant rate thus, formation of a liquid

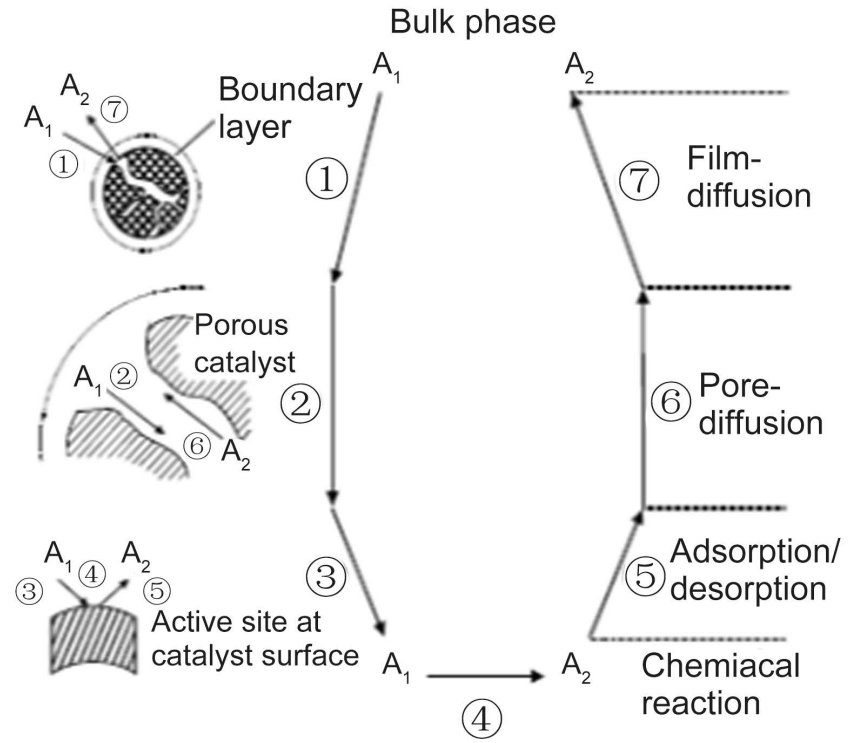

Figure 1. Individual steps of a simple, heterogeneous catalytic fluid-solid reaction $A_{1} \rightarrow$ $\mathrm{A}_{2}$ carried out on a porous catalyst [41]. 
film surrounding the adsorbent particles takes place through the proper concentration gradient [38]. In order to predict the actual slow step involved in the adsorption process, the kinetic data were further analyzed using the Boyd model equation $\left[B_{t}=-0.4977-\ln (1-F)\right]$.

Where, $F$ Represents the fraction of solute adsorbed at any time, $t(h)$, as calculated by, $F=q_{t} / q_{o}$. When $B_{t}$ vs. $t(h)$ plotted and if the linear lines pass through the origin the rate limiting step become particle diffusion if not it governed by external mass transport mechanism [39] [40], reported the adsorption of 2, 4, 6-trichlorophenol on the prepared activated carbon from Boyd plot and mainly governed by particle diffusion.

During all the above mentioned processes, two main types of interaction, namely, physical and chemical, are possible between adsorbent and adsorbate [42]; the former is known as physisorption, and the latter is chemisorption. Physisorption is a result of attractive forces between sorbent and adsorbate molecules, whereas chemisorption provides a stronger bond as it involves the transfer or sharing of electrons between adsorbent and adsorbate species. As a guideline, heat of adsorption with magnitude between 5 and $40 \mathrm{~kJ} / \mathrm{mol}$ indicates physisorption as the dominant adsorption mode, while the other between 40 and 125 $\mathrm{kJ} / \mathrm{mol}$ indicates chemisorption [43].

\subsection{Type of Adsorption Isotherm}

There are six different types of adsorption isotherms as shown in Figure 2. Type one (I) adsorption isotherm is for very small pores or microporous adsorbents. In this case adsorption occurs by filling of the micropores. The adsorbate adsorption rate depends on the available micropore volume instead total interior surface area. Type two (II) and type four (IV) adsorption isotherms were detected for non-porous or macroporous adsorbents with unlimited monolayer-multilayer adsorption. First the adsorption volume quickly increases at low relative pressures due to contact of the adsorbate molecules with the higher energetic section followed by the interaction with less energetic section.

When the monolayer formation of the adsorbed molecules is complete, multilayer formation starts to take place corresponding to the "sharp knee" of the isotherms. As the relative pressure approaches unity a sudden rise shows the bulk condensation of adsorbate gas to liquid. Finally, type three (III) and type four (V) isotherms do not have the "sharp knee" shape indicating that a stronger adsorbate-adsorbate interactions than adsorbate-adsorbent interaction.

\subsection{Adsorption Equilibrium}

Adsorption equilibrium information is the most important piece of information needed for a proper understanding of an adsorption process. A proper understanding and interpretation of adsorption isotherms is critical for the overall improvement of adsorption mechanism pathways and effective design of adsorption system. But most of the studies apply only Langmuir and Freundlich 


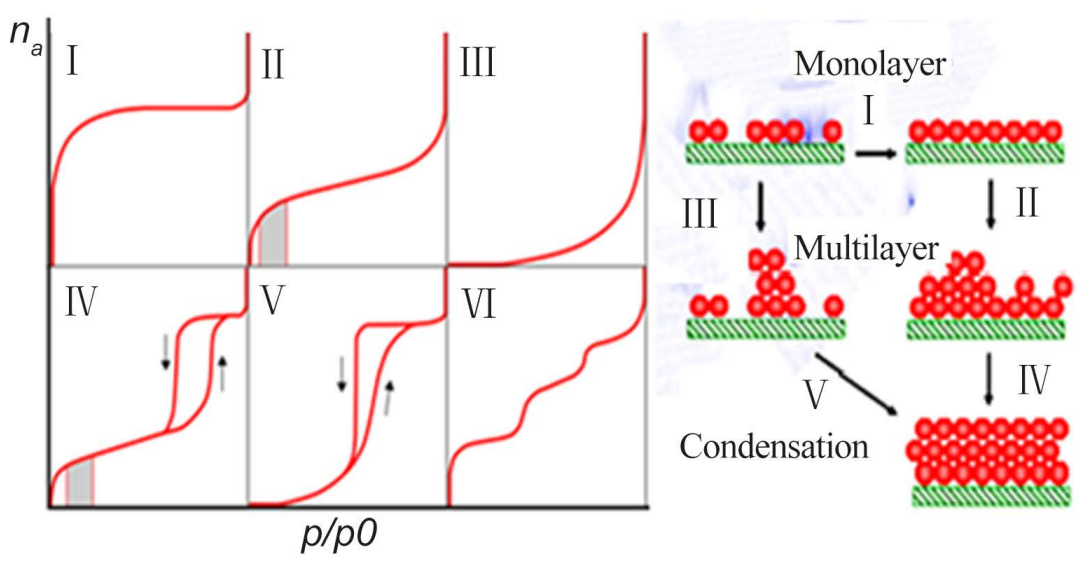

Figure 2. IUPAC classification of adsorption isotherms (typical BET range is indicated in Types II and IV by the shaded areas) $n_{a}$ is quantity of absorbed gas, $p / p_{o}$ is the relative pressure [44].

models and depending on coefficient of determination $\left(R^{2}\right)$ values the mechanism of adsorption judged by declaring the process as physical, chemical or both. Since most those models fits well with different experimental data, confirming with other models to know whether those models are perfect or not become the most important requirement. The selective mini review is presented in the Table 1.

As an example [45] (2012) a researcher applied Langmuir, Freundlich, Temkin and Dubinin-radushkevich isotherms studies of equilibrium sorption of $\mathrm{Zn}^{2+}$ onto phosphoric acid modified rice husk. Among those four adsorption isotherm models, the $\mathrm{R}^{2}$ value of Langmuir isotherm model was the highest and the heat of sorption process was estimated from Temkin isotherm model to be 25.34 $\mathrm{J} / \mathrm{mol}$ and the mean free energy was estimated from DR-K isotherm model to be $0.7 \mathrm{KJ} / \mathrm{mol}$ which vividly proved that the adsorption experiment followed a physical process. On this studies the well-fitting of Langmuir isotherm model were confirmed by Temkin and DRK. Different models and their uses as well as the linear and nonlinear sorption isotherms equations are presented in Table 2. During adsorption study to understand the machoism of adsorption it is advisable to apply at list adsorption isotherm models present in bold red in Table 2 and Table 3 for kinetics of adsorption. Common nomenclatures of equations are given at the end above the references.

\subsection{Adsorption Kinetics}

Kinetics of adsorption using the statistical least squares method, several adsorption studies fit the PFO and PSO models. Therefore, without applying any work used to reduce/eliminate the diffusion-adsorption mechanism (transport influences; like intra particle diffusion), deciding the mechanism of adsorption only depending on adsorption-reaction models become wrong interpretation of mechanism of kinetics of adsorption. Generally suggested by earlier research group, [35] PFO and PSO is not a model of defined mechanism but, rather, they are a 
Table 1. Selective mini review.

\begin{tabular}{|c|c|c|c|c|}
\hline Adsorbate & Adsorbent & Fitted Isotherm & Fitted Kinetics & Ref. \\
\hline $\mathrm{Pb}(\mathrm{II})$ & Illite/Smectite Clay & Langmuir & - & [4] \\
\hline $\mathrm{Hg}(\mathrm{II})$ & $\begin{array}{c}\text { activated Carbon from } \\
\text { Rosmarinusofficinalis leaves }\end{array}$ & Langmuir & PSO & [72] \\
\hline Phosphate anion & Membranes & Flory-Huggins & - & [51] \\
\hline As & Fe -Ti bimetal oxides & Freundlich \& Langmuir & $\mathrm{PFO}$ & [73] \\
\hline Atrazine & Eucalyptus tereticornis L. (EB) & $\begin{array}{l}\text { Freundlich, Koble-Corrigan, Toth } \\
\text { and Fritz-Schluender }\end{array}$ & PSO & [74] \\
\hline Imidacloprid & & & $\mathrm{PFO}$ & \\
\hline Reactive Black 5 & Bentonite clay & Harkin-Jura and Freundlich & PSO & [75] \\
\hline $\mathrm{Cu}(\mathrm{II})$ & Peanut hulls & Langmuir & PFO, PSO \& Elovich & [1] \\
\hline Rhodamine B (RhB) & Raphiahookerie fruit epicarp & Freundlich & PSO \& Elovich & [76] \\
\hline 2,4,6-trichlorophenol & $\begin{array}{l}\text { oil palm empty fruit bunch-based } \\
\text { activated carbon }\end{array}$ & Freundlich \& RP & PSO \& Boyd-IPD & [40] \\
\hline $\begin{array}{c}\text { Maxilon blue GRL, and direct } \\
\text { yellow DY } 12\end{array}$ & Activated carbon from coconut husk & $\begin{array}{l}\text { Fritz-Schlunder (heterogeneous with } \\
\text { multi-layers) }\end{array}$ & PSO & [77] \\
\hline $\mathrm{Zn}^{2+}$ & Phosphoric Acid Modified Rice Husk & $\begin{array}{c}\text { Langmuir } \\
25 \mathrm{~J} / \mathrm{mol} \text { (Temkin) } \\
0.7 \mathrm{~kJ} / \mathrm{mol}(\mathrm{DRK})\end{array}$ & - & [45] \\
\hline Cd (II) & $\begin{array}{l}\text { Chitosan and methyl orange onto } \\
\text { bentonite }\end{array}$ & $\begin{array}{c}\mathrm{R}^{2} \text { insufficient to decide: } \Delta q(\%) \& \\
\text { other should be used }\end{array}$ & Nonlinear than linear & [78] \\
\hline
\end{tabular}

Table 2. Models of adsorption isotherms [46].

\begin{tabular}{|c|c|c|c|}
\hline Isotherms & Isotherm Equation & Uses and notes & Ref. \\
\hline \multicolumn{4}{|c|}{ One-Parameter Isotherm } \\
\hline Henry's & $q_{e}=K_{H E} C_{e}$ & \multicolumn{2}{|l|}{ Simplest adsorption isotherm } \\
\hline & & Two-Parameter Isotherm & \\
\hline Hill-Deboer & $\begin{array}{c}\ln \left[\frac{C_{e}(1-\theta)}{\theta}\right]-\frac{\theta}{1-\theta}=-\ln k_{1}-\frac{k_{2} \theta}{R T} \\
k_{1} C_{e}=\frac{\theta}{1-\theta} \exp \left(\frac{\theta}{1-\theta}-\frac{k_{2} \theta}{R T}\right)\end{array}$ & $\begin{array}{l}\text { Defines the case where there is mobile adsorption and lateral interaction and } \\
K_{2} \text { is the energetic constant of the interaction between adsorbed molecules } \\
\left(\mathrm{kJ} \cdot \mathrm{mol}^{-1}\right)\end{array}$ & [47] \\
\hline $\begin{array}{l}\text { Fowler- } \\
\text { Guggenheim }\end{array}$ & $\begin{array}{c}\ln \left[\frac{C_{e}(1-\theta)}{\theta}\right]=-\ln k_{F G}+\frac{2 w \theta}{R T} \\
k_{F G} C_{e}=\frac{\theta}{(1-\theta)} \exp \left(\frac{2 w \theta}{R T}\right)\end{array}$ & $\begin{array}{l}\text { Side contact between adsorbed molecules and the heat of adsorption }(w) \\
\text { varies linearly with loading. If attractive, } w=\text { positive, repulsive } w=\text { negative } \\
\text { and } w=0 \text { no interaction between absorbate. But applicable only if } \theta<0.6\end{array}$ & [47] \\
\hline Langmuir & $\begin{aligned} q_{e} & =\frac{q_{m} k_{L} C_{e}}{1+k_{L} C_{e}} \\
\frac{C_{e}}{q_{e}} & =\frac{1}{q_{m} k_{L}}+\frac{C_{e}}{q_{m}} \\
R_{L} & =\frac{1}{1+k_{L} C_{o}}\end{aligned}$ & $\begin{array}{l}\text { Homogeneous binding sites (same affinities), alike sorption energies, and no } \\
\text { interactions between adsorbed species. } R_{L} \text { is separation aspect which decides } \\
\text { whether the adsorption is un-favorable when its value is }>1 \text {, linear }(=1) \text {, } \\
\text { favourable }\left(0<R_{L}<1\right) \text {, and irreversible }\left(R_{L}=0\right)\end{array}$ & [48] \\
\hline Freundlich & $\begin{array}{c}q_{e}=k_{f} c_{e}^{1 / n} \\
\log q_{e}=\log k_{F}+\frac{1}{n} \log c_{e}\end{array}$ & $\begin{array}{l}\text { Heterogonous surfaces(varied affinities), } 1 / n \text { (adsorption intensity) that } \\
\text { specifies the energy and the heterogeneity of the adsorbent sites }(1 / n<1= \\
\text { Langmuir, } 1 / n>1 \text { cooperative adsorption and generally, } \mathrm{n} \text { in } \mathrm{b} / \mathrm{n} 2-10 \\
\text { indicates good favorability of sorption }\end{array}$ & [49] \\
\hline
\end{tabular}




\section{Continued}

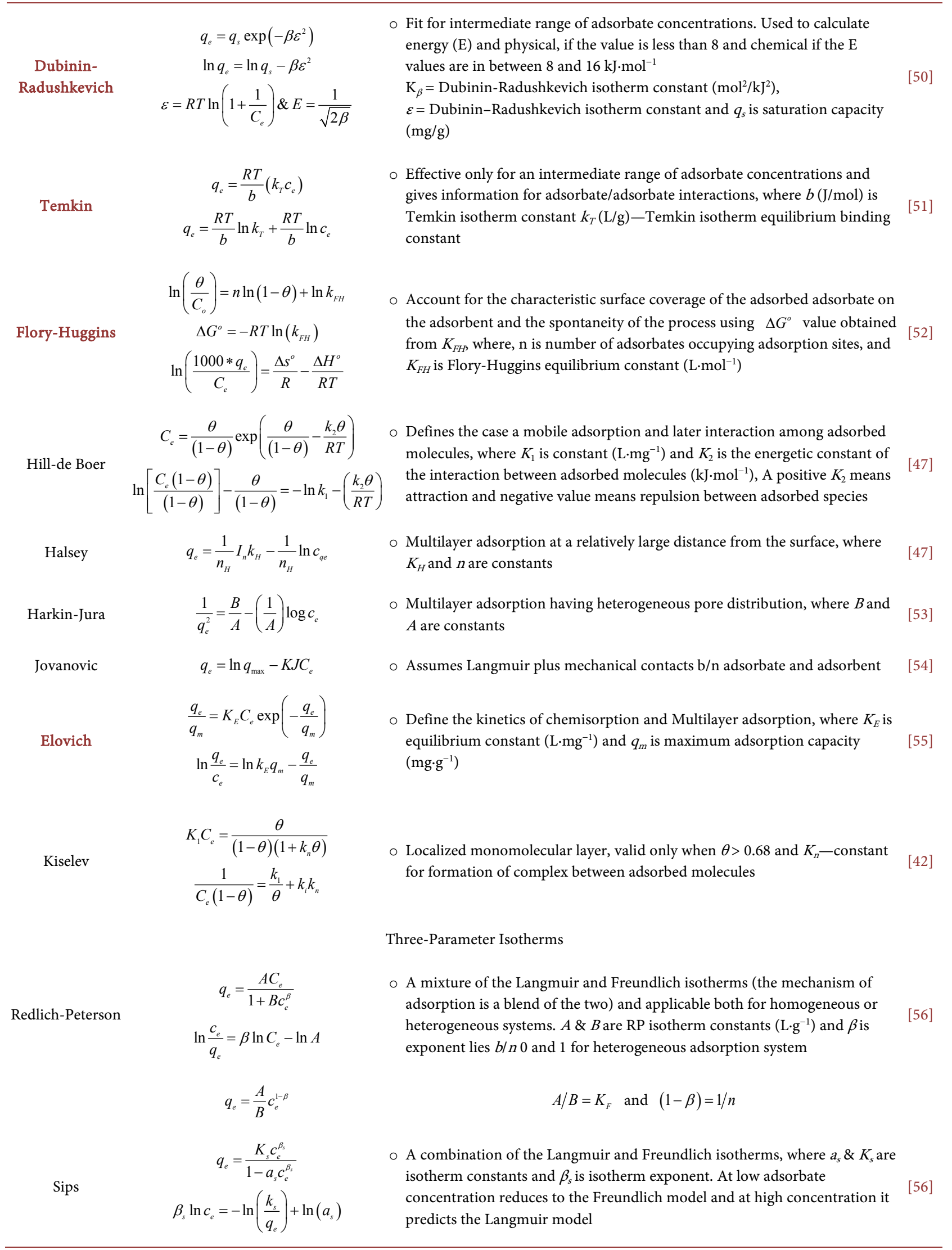




\section{Continued}

Koble-Carrigan

Kahn

Radke-Prausniiz

Langmuir-

Freundlich

Jossens

Fritz-Schlunder

Bauder

Weber-Van Vliet

Marczewski-Jaroniec

$q_{e}=q_{M M J}\left[\frac{\left(k_{M J} C_{e}\right)^{n_{M J}}}{1+\left(k_{M J} C_{E}\right)^{n_{M J}}}\right]^{\frac{M_{M J}}{n_{M J}}}$
- Modification of the Langmuir equation and describes heterogeneous systems which satisfy both low and high end boundary of adsorbate concentration, both $K_{L} \& n$ is isotherm constant and when $n=1$ reduces to Langmuir \& $n$ far from 1 shows heterogeneity, this where evaluated by nonlinear curve fitting method using sigma plot software

○ A combination of both Langmuir and Freundlich isotherms and all $A_{\mathrm{k}}, B_{k}$ and $p$ are isotherm constant. Solver add-in function of the Microsoft Excel and valid only when $p \geq 1$

$\circ$ Used for adsorption of bi-solute sorption in dilute solution, where, $a_{k}$ is isotherm exponent and $b_{k}$ is isotherm constant

○ Chose at low concentrations, where $q_{\mathrm{MRP}}=q_{\max }, K_{R P}$ is equilibrium and constant and MRP is exponent

- Reduces to linear at low concentration, at high [ ] reduces to Freundlich and When MRP $=0$ becomes Langmuir isotherm model

- At low concentration becomes Freundlich and at high becomes the Langmuir isotherm model, where, $q_{M L F}=q_{\max }, K_{L F}$ is constant for heterogeneous solid; $\mathrm{n}$ is heterogeneity index lies $\mathrm{b} / \mathrm{n} 0$ and 1 .

- Work based on energy distribution of adsorbate-adsorbent interactions at heterogeneous adsorption sites, where $H$ (Henry's), $p \& F$ are constants

$\circ p$ is characteristic of the adsorbent regardless of temperature and the nature.

Four-Parameter Isotherms

- Due to large number of coefficients, makes it to fit a wide range of experimental results, where, $q_{m F S}=q_{\max }, K_{F S}$ is equilibrium constant and MFS is exponent. And if MFS $=1$ it becomes the Langmuir and high concentrations reduces to Freundlich, The constants are evaluated by nonlinear regression analysis.

○ Used to estimate the Langmuir coefficients ( $b$ and $q_{m l}$ ) by measurement of tangents at different equilibrium concentrations shows that they are not constants in a broad range, where $b_{o}$ is equilibrium constant and $x$ is \& $Y$ is parameters

○ Describe wide range of adsorption systems, where $p_{1}, p_{2}, p_{3}, \& p_{4}$ are isotherm parameters which defined by multiple nonlinear curve fitting method.

$\circ$ General Langmuir equation, where $n_{M J}$ and $M_{M J}$ are parameters characterize the Tells the Heterogeneity of the surface, where $M_{M J}$ describes the spreading of distribution in the path of higher adsorption energy, and $n_{M J}$ lesser adsorption energies

Five-Parameter Isotherms

○ Define more wide range of adsorption systems, where $q_{m F S}=q_{\max }$ and $K_{1}, K_{2}$, $\alpha_{F S} \& \beta_{F S}$ are parameter constants. And this model approaches Langmuir model when the value of $\alpha_{F S}$ and $\beta_{F S}$ equals 1; for higher concentrations it reduces to Freundlich model.

$$
q_{e}=\frac{q_{m} F S_{s} K_{1} C_{e}^{\alpha_{F S}}}{1+k_{2} C_{e}^{\beta_{F S}}}
$$

highly flexible formula that combines many different models with different controlling mechanisms. The rate constants obtained was the result of complex interaction between different controlling mechanisms which are simply empirical 
Table 3. Adsorption models of Kinetics [35].

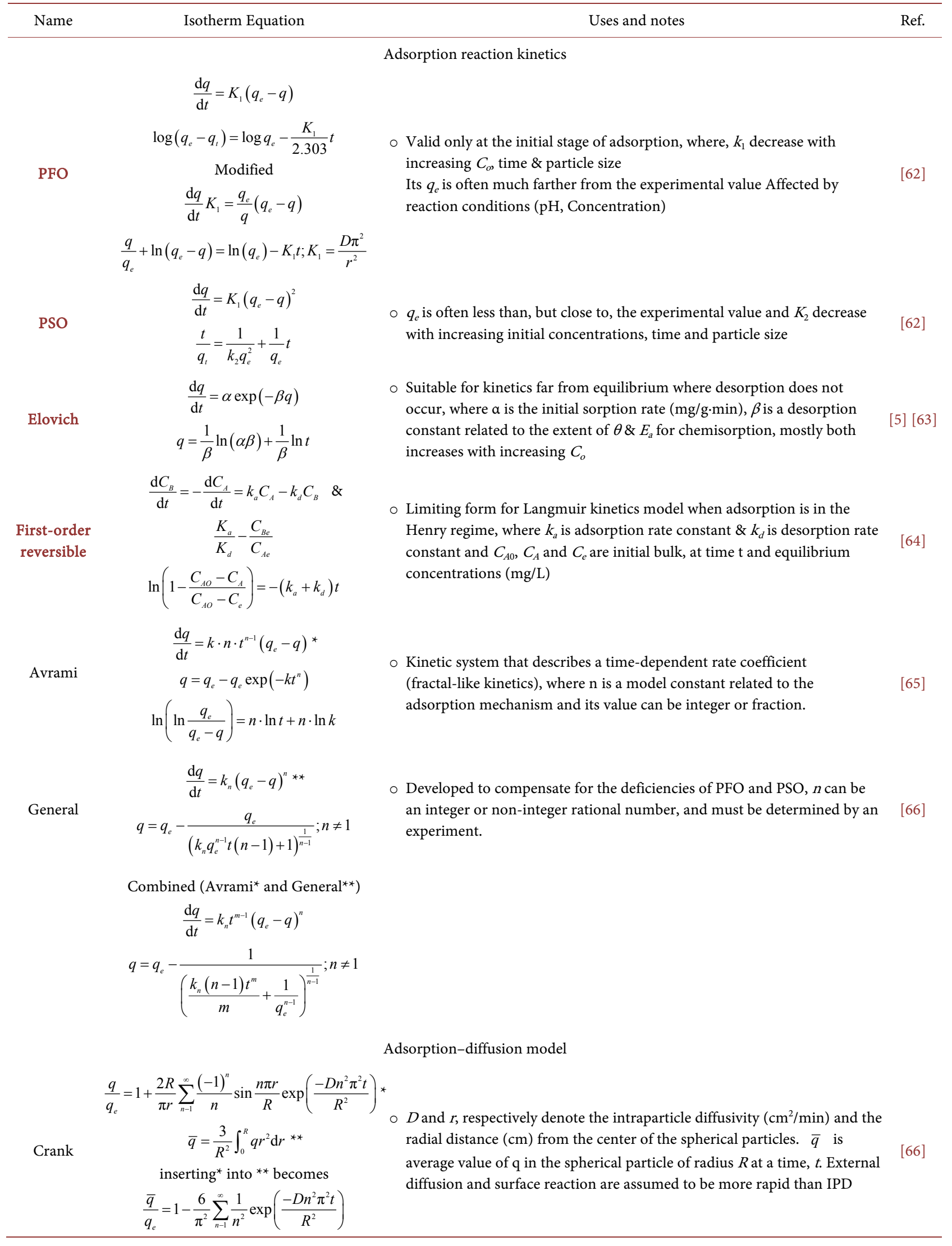




\section{Continued}

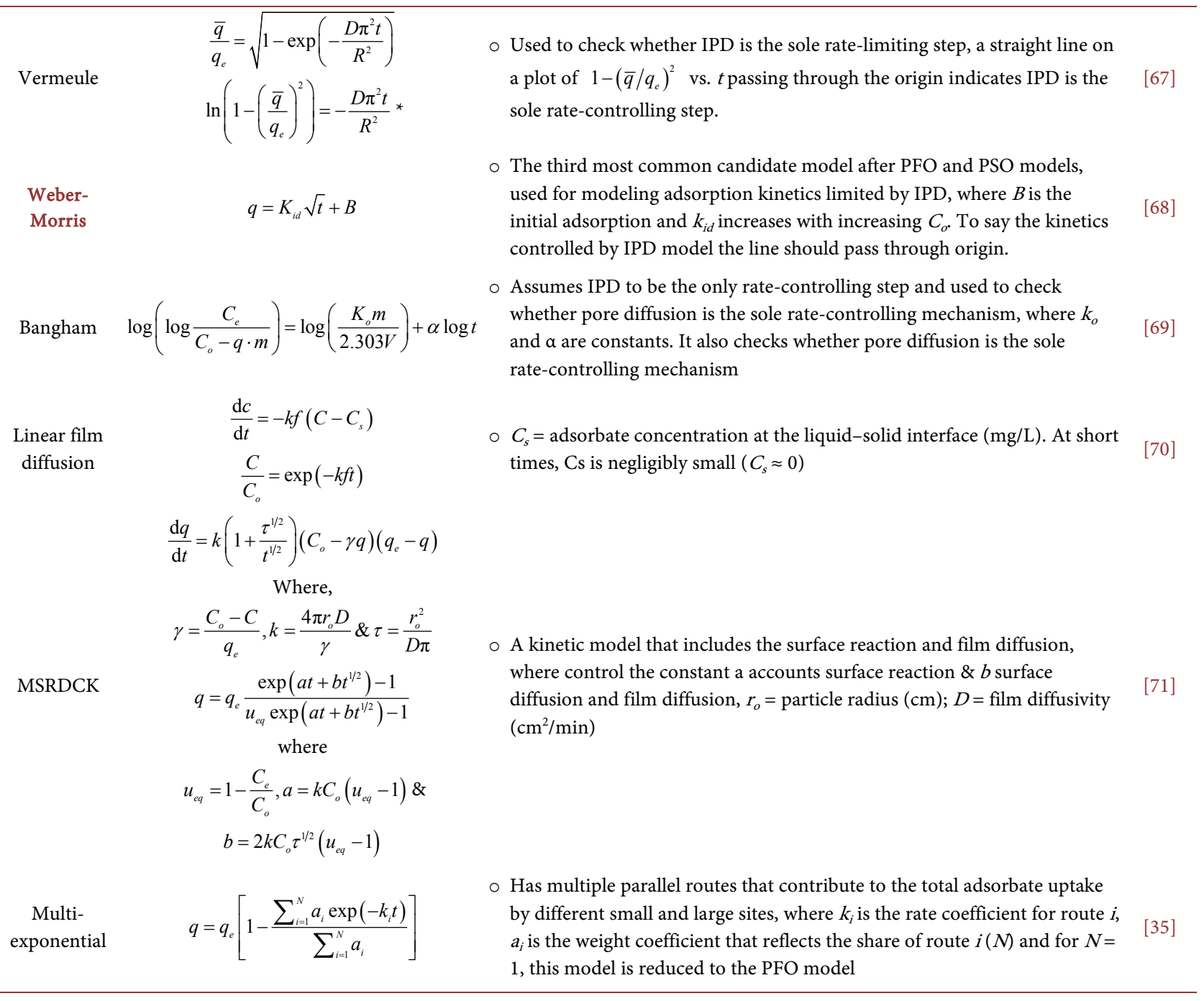

constants without physicochemical meaning and provide little insights into adsorption mechanisms and no meaningful mechanism can be confidently postulated from these models. In addition to the mechanism of reaction, it is necessary to calculate important sorption parameters like adsorption activation energy with the help of Arrhenius equation $D_{s}=D_{s o} \exp \left(-E_{a} / R T\right)$ [61]. The linear and nonlinear formula of sorption kinetics and their use are indicated in Table 3.

\subsection{The Nonlinear and Linear Fitness of Adsorption}

The nonlinear and linear models were used to define the kinetics curves. Their validities can be determined using coefficient of determination $\left(R^{2}\right)$ and standard deviation (SD) $\Delta q$ (\%) [78]. In most of sorption studies the linearized form of PFO, PSO and other relevant models are determined based on the correlation of determination $\left(R^{2}\right)$ value, and the obtained model parameters are cross-checked with the experimental values. But, the linearized forms of the PFO and PSO 
model provide sometimes-widely different parameter values. Nonlinear regression is recommended to avoid this problem, and it has been shown to be better than linear regression. It gives more realistic values of $q_{e}$ and $k$, and most of the times a $R^{2}$ value. But, Regardless of its popularity it does not penetrate deep into the community.

Most linear regression creates discrimination on PFO than PSO based on $\mathrm{R}^{2}$ values decision. Some studies qualified to PSO by linear regression, surprisingly fits PFO by nonlinear regression [79]. In addition, PFO is prone to experimental error, whereas PSO is less sensitive to experimental error, but the nonlinear regression evaluates both PFO and PSO equally towards experimental error. Therefore comparison of the linear and nonlinear models in terms of fit quality and reasonability of the determined parameters before deciding on the best model becomes the most acceptable procedure to reduce statistical discrimination bias [80].

Linear regression is a method used to model the association among a scalar dependent variable and one independent variable. The well-fitting line is the line that reduces the sum of the squared errors (SSE) of prediction. The strength of the linear association between two variables is quantified by the square of the correlation coefficient $(R)$ which is known as the determination of the coefficient $\left(R^{2}\right)$. The higher $R^{2}$ value (lower values of error functions) indicates a stronger linear relationship.

Nonlinear regression can be a dominant substitute to linear regression because it suggests the most flexible curve fitting functionality. For nonlinear model, sum of square must be minimized by an iterative method. The nonlinear regression line is the line that minimizes the sum of squared deviations of prediction (also called the sum of squares error). The standard error of the estimate (S) is the square root of the average squared deviation. This parameter measures the accuracy of predictions. The smaller the standard error of the estimate indicates the more accurate prediction. In nonlinear regression, good of fitness method is used after error analysis.

\subsection{Error Functions}

Error functions (Table 4) are statistics that measure the error between the model parameters and experimental values. It was a standard method developed based on the least squares criterion. Model parameters are captured well by the slope and intercept, both of which are clearly defined as functions of the experimental data. The fitted parameters are set by regression to minimize the sum-of-squares errors between the predicted and experimental values.

In the literature, these error statistics were calculated in addition to the correlation of determination $\left(R^{2}\right)$ to confirm and support the model already discriminated by $R^{2}$. High $R^{2}$ values correspond to low error statistics in most cases. When $R^{2}$ values are too near to discriminate the PFO and PSO models, RMSE comes in convenient [81]. Roughly well-known error functions are listed in table. When its value is nearer to unity indicates a well fit. 
Table 4. Error function.

\begin{tabular}{|c|c|c|c|}
\hline Name & Error equation & Note & Ref. \\
\hline SSE/ERRSQ & $\sum_{i=1}^{n}\left(q_{e, c a l}-q_{e, e x p}\right)^{2}$ & $\begin{array}{l}\text { It is indicator for accuracy, in which the best fit of the data can be assessed from the } \\
\text { sum-of-squares value. The smallest value for SSE indicates the best fit data for the } \\
\text { model. }\end{array}$ & {$[82]$} \\
\hline HYBRID & $\sum_{i=1}^{n} \frac{100}{n-p}\left[\frac{\left(q_{e, \text { meas }}-q_{e, c a l}\right)}{q_{e, \text { meas }}}\right]$ & The error function was developed to improve ERRSQ fit at low concentrations. & [83] \\
\hline ARE & $\frac{100}{n} \sum_{i=1}^{n}\left|\frac{\left(q_{e, \text { meas }}-q_{e, \text { cal }}\right)}{q_{e, \text { meas }}}\right|$ & $\begin{array}{l}\text { which indicates a tendency to under or overestimate the experimental data, } \\
\text { attempts to minimize the fractional error distribution across the entire studied } \\
\text { concentration range }\end{array}$ & [84] \\
\hline$x^{2}$ & $\sum_{i=1}^{n} \frac{\left(q_{e, c a l}-q_{e, \mathrm{exp}}\right)^{2}}{q_{e, c a l}}$ & $\chi^{2}$ is also similar to SSE. Smaller values of $\chi^{2}$ also indicate a better fit of the model. & [69] \\
\hline SE & $\sqrt{\frac{1}{n} \sum_{i=1}^{n}\left(q_{e, c a l}-q_{e, e x p}\right)^{2}}$ & $\begin{array}{l}\text { It is also used to judge the equilibrium model. A smaller value for SE indicates a } \\
\text { better fit of the model }\end{array}$ & [84] \\
\hline$\Delta q(\%)$ & $100 \sqrt{\frac{1}{n-1} \sum_{i=1}^{n}\left(\frac{q_{e, \text { meas }}-q_{e, c a l}}{q_{e, \text { meas }}}\right)^{2}}$ & $\begin{array}{l}\text { According to the number of degrees of freedom in the system, it is similar to some } \\
\text { respects of a modified geometric mean error distribution }\end{array}$ & \\
\hline$R^{2}$ & $\frac{\sum_{i=1}^{n}\left(q_{c a l}-\overline{q_{e x p}}\right)^{2}}{\sum_{i=1}^{n}\left(q_{e, c a l}-\overline{q_{e, e x p}}\right)^{2}+\sum_{i=1}^{n}\left(q_{e, c a l}-q_{e, e x p}\right)^{2}}$ & $\begin{array}{l}\text { The correlation coefficient }\left(R^{2}\right) \text { is the common measure of analytical accuracy. Its } \\
\text { value is within the range of } 0<R^{2} \leq 1 \text {, where a high value reflects an accurate } \\
\text { analysis. }\end{array}$ & [85] \\
\hline SAE & $\sum_{i=1}^{n}\left|q_{e, \text { mass }}-q_{e, c a l}\right|$ & $\begin{array}{l}\text { with an increase in the errors will provide a better fit, leading to the bias towards } \\
\text { the high concentration data }\end{array}$ & [84] \\
\hline $\mathrm{S}_{\mathrm{RE}}$ & $\sqrt{\frac{\left.\left[\sum_{i=1}^{n}\left(q_{e, \text { mass }}-q_{e, c a l}\right)-\mathrm{ARE}\right)^{2}\right]}{n-1}}$ & & [84] \\
\hline
\end{tabular}

The past study [78] compared the linear and nonlinear equations of pseudo-first order and pseudo-second order kinetic models on adsorption of Cd (II) onto chitosan and methyl orange onto bentonite. For validation standard deviation (SD) $D q$ (\%) and the coefficient of determination $R^{2}$ values was used. The conclusion was that the nonlinear models are more appropriate than linear forms for the modeling of the kinetics of adsorption in liquid phase and it is noted that the determination of $R^{2}$ alone is inadequate to decide. Therefore, using the error functions like standard deviation $\Delta q(\%)$ in addition to $\mathrm{R}^{2}$ value is supportive.

\section{Photocatalysis}

Numerous water treatment techniques such as, adsorption, membrane separation, coagulation, etc., have been engaged using nano materials (having unique electronic, optical, magnetic and mechanical properties) to remove pollutants. Nevertheless, these techniques only focus on changing the pollutants from aqueous solution to solid phase [86]. For this reason, advanced oxidation processes (AOPs) should be used to degrade organic pollutants after adsorption on the catalyst.

From promising photocatalyst or adsorbent, nowadays, metal oxide nanoma- 
terials, such as zinc oxide $(\mathrm{ZnO})$, titanium dioxide $\left(\mathrm{TiO}_{2}\right)$, aluminium oxide $\left(\mathrm{Al}_{2} \mathrm{O}_{3}\right)$, iron (III) oxide $\left(\mathrm{Fe}_{2} \mathrm{O}_{3}\right)$, copper oxide $(\mathrm{CuO})$, zirconia $\left(\mathrm{ZrO}_{2}\right)$, vana$\operatorname{dium}(\mathrm{V})$ oxide $\left(\mathrm{V}_{2} \mathrm{O}_{5}\right)$, niobium pentoxide $\left(\mathrm{Nb}_{2} \mathrm{O}_{5}\right)$ and tungsten trioxide $\left(\mathrm{WO}_{3}\right)$ have been actively useful in environmental wastewater management scheme [87]. Among these, $\mathrm{ZnO}$ is an environmentally safe metal oxide and has non-toxic nature with existing organisms.

Similar to $\mathrm{TiO}_{2}, \mathrm{ZnO}$ is an n-type metal oxide but has not been well studied in earlier studies. It has been proposed as another photocatalyst similar to $\mathrm{TiO}_{2}$ as it possess same band gap energy $(3.2 \mathrm{eV})$ but gives higher absorption efficacy across a large fraction of the solar spectrum (large free-exciton binding energy) [88]. It is also inexpensive (75\% lower production cost) relative to $\mathrm{TiO}_{2}$ [89]. The main drawbacks of $\mathrm{ZnO}$ are, its dissolution at acidic $\mathrm{pH}$, corrosion in alkaline $\mathrm{pH}$, fast recombination of photogenerated charges and lack of visible light absorption [5].

\subsection{Recombination and Visible Light Response}

In the past substantial efforts such as: doping with impurities/dopant [90], formation of nanocomposites [91], surface modification, dye sensitization [92], noble metal deposition [93], non-noble metal deposition [94], sensitizing with narrow bandgap absorption materials ( $\mathrm{Eg}<3.0 \mathrm{eV}$; like: $\mathrm{CdS}, \mathrm{ZnS}$, etc.), organic dyes, conducting polymers and inorganic metal complexes [95] and hydrogenation procedure (annealing under hydrogen atmosphere) are studied for allowing visible light absorption of high band gap metal oxides (such as: $\mathrm{TiO}_{2}, \mathrm{ZnO}, \ldots$ ). The hetro-junction of those high band gap metal oxides with other low band gap materials get attention due to not only induces visible light sensitization for the composite but also for it enabling the oxidation and reduction reactions to arise at different components. But those methods are also not well-organized enough to induce enough visible light absorption. The combination of these hetro-junction leading to multiple alterations (such as: simultaneous doping-sensitization, doping-deposition, deposition-coupling, etc.) are also are become the alternative towards improvement of visible light absorption [96]. Also functionalizing of the metal oxide surface [using the bifunctional linking or with citric acid molecule] enables the connection of larger amount of low band gap semiconductor materials [8].

In order to decrease the recombination of photogenerated electron-hole pairs (charge carrier separation enhancement), structural stability and for isolation of the redox sites at various modification methods (such as: integrating with equivalent bandgap materials, designing with exposed reactive facets, modification with carbon nanostructures and hierarchical morphologies coupling two semiconductors) have been through. Among those methods researchers choose coupling of two/more semiconductors metal oxides having related or different band gaps $\left(\mathrm{TiO}_{2} / \mathrm{ZnO}, \mathrm{SnO}_{2} / \mathrm{ZnO}, \mathrm{SnO}_{2} / \mathrm{ZnO} / \mathrm{TiO}_{2}\right.$ and $\mathrm{Co}_{3} \mathrm{O}_{4} / \mathrm{ZnO}$ ) [6] [7] [14] [97], due to continuous transfer of photo-generated electrons and holes from 
one semiconductor to another [98] [99].

For the reason that, the nanocomposite improves light absorption effectiveness, prevention of photo corrosion, increases sun light absorption, new functionalities get up at the interfacial, change in surface acid-base behavior and better suppression of electron hole recombination [100]. Specially, the tricomposites are more energetic towards suppression of electron hole recombination, because, unidirectional charge transfer (interelectron transfer) within the stepwise electronic band structure between the catalyst [97]. On the other studies coupling of bare metal oxide with its doped counterparts (example: $\mathrm{N}-\mathrm{ZnO}$ coupled $\mathrm{ZnO}$ ) enhanced the charge carrier separation, free radical generation and visible light response [18] [19]. Explanation of different ways used to increase the visible light response, structural stability, altering the defect chemistry with improved charge carrier separation procedures are shown in Figure 3.

\subsection{Parameter Optimization}

In addition to the electron-hole recombination and visible light response, deep awareness on factors affecting photo-degradation, as well as, adsorption effectiveness, such as: catalyst/dosage loading (which controls light scattering, screening effects, turbidity and agglomeration) [101] [102], catalyst structure (surface area) [103], solution $\mathrm{pH}$ (surface charge, positions of VB and CB) [104], light intensity [105], light wavelength (around $254 \mathrm{~nm})$ [106], temperature $\left(20^{\circ} \mathrm{C}-80^{\circ} \mathrm{C}\right)$ [107], inorganic species $\left(\mathrm{H}_{2} \mathrm{O}_{2}[108], \mathrm{S}_{2} \mathrm{O}_{8}^{2-} \quad[33], \mathrm{BrO}_{3}^{-}\right.$[34], $\mathrm{SO}_{3}^{-}$[32]) should also be taken in to consideration.

\subsection{Synthesis Methods}

Among different metal oxide nanomaterial synthesis methods, the solution-based approach is the simplest, least energy consuming and easy to control the morphology, as well as, sizes of the nanomaterials by handling the experimental factors such as type of solvents with different dielectric constant, starting materials (precursor) concentration, reaction solution $\mathrm{pH}$, mineral acids, etc. [21] [109]. The chemical approach normally involves reduction of metal ions into metal atoms in the existence of stabilizing agents, followed by the controlled aggregation of atoms. Those approaches used in the synthesis of modified metal oxides includes:

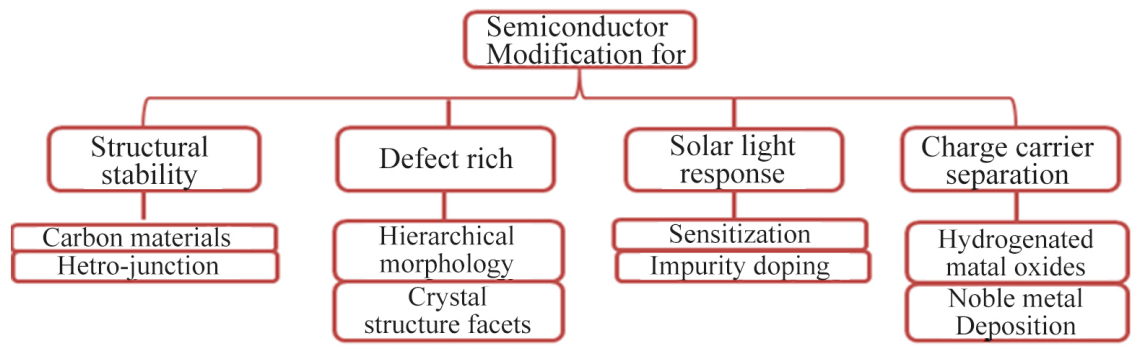

Figure 3. Universal approaches to tailor the surface-bulk electronic structure of semiconducting photo catalysts for improving the visible light response, structural stability, altering the defect chemistry with improved charge carrier separation processes [96]. 
impregnation method [22], hydrothermal [24], sol-gel [110], co-precipitation, flame spray pyrolysis, micro-emulsion, electrochemical deposition process, solvothermal, microwave, polyol, flux methods, electrospinning, solid state dispersion method etc. [111] [112].

Among these approaches, the sol-gel procedure is the most attractive method towards low production cost, good, high reliability, repeatability, simplicity of the process, low process temperature, ease of control of physical characteristics \& morphology of nanoparticles, good compositional homogeneity and optical properties [29]. In addition to advance the photoactivity, various methods such as: controlling adding rate of precursors (example: sodium hydroxide), adding of selective capping agents, have been used to adjust the chemical properties of the materials, elemental composition, shape, morphology, size and growth of the nanostructure materials [113]. As an example among different shapes of $\mathrm{ZnO}$ nanostructures, spherical nanostructures were reported to exhibit the highest degradation rate of organic pollutants ascribed to their large oxygen vacancies. Not controlling those different parameters/conditions the toxicity of the reagent added must be taken in to consideration. In this context, ongoing research has modified the existing sol-gel technique by using only water as solvent [114]. Due to the existence of $\mathrm{M}-\mathrm{O}-\mathrm{M}$ bonds in metal oxides nanoparticles, agglomeration occurs readily [115]. This agglomeration of nanomaterials to each other strongly limits the adsorption, as well as, photo catalysis of nanoparticle. Among different agglomeration inhibition methods such as, chemical treatment [116] coating [115], grafting polymerization [117], ligand exchange [115] and self-assembly [118]) techniques, ligand exchange are the one which is nicely acknowledged.

\subsection{Mechanism, Electronic Arrangement and $\mathrm{e}^{-} / \mathrm{h}^{+}$Separation of Composites}

Photo-catalysis defined as "catalysis driven acceleration of a light-induced reaction", the detailed scheme of semiconductor photo-catalyst reaction was summarized in Figure 4(a). First before degradation starts the organic pollutants should diffuse and adsorbed on the external surface of catalyst/semiconductor. Therefore, selection/modification of the adsorbent for specific adsorbate become the key point, because, without adsorption no degradation takes palaces. After adsorption when ultraviolet/visible light energy (hv) (equal or greater than the excitation energy/band gap) interacts with catalyst/semiconductor, as a result of excitation of electron $\left(\mathrm{e}^{-}\right)$from valance band $(\mathrm{VB})$ to conduction band $(\mathrm{CB})$ the production of $\mathrm{e}^{-} / \mathrm{h}^{+}$pairs occurs. Migration of those $\mathrm{e}^{-} / \mathrm{h}^{+}$pair on the surface of the catalyst and interacting with other species, like, water or oxygen redox reaction will takes palaces. On oxidation reaction $\mathrm{H}_{2} \mathrm{O}\left(\mathrm{OH}^{-}\right)$reacts with catalyst holes $\left(\mathrm{h}_{\mathrm{VB}}^{+}\right)$results in formation of hydroxyl radicals $\left(\mathrm{OH}^{*}\right)$. And on reduction reaction the exited electrons reacts with oxygen from the air for the formation of superoxide radicals $\left(\mathrm{O}_{2}^{--}\right)$. The superoxide radicals will further protonated to harvest hydro-peroxyl radical $\left(\mathrm{HOO}^{\circ}\right)$ and subsequently hydrogen peroxide 


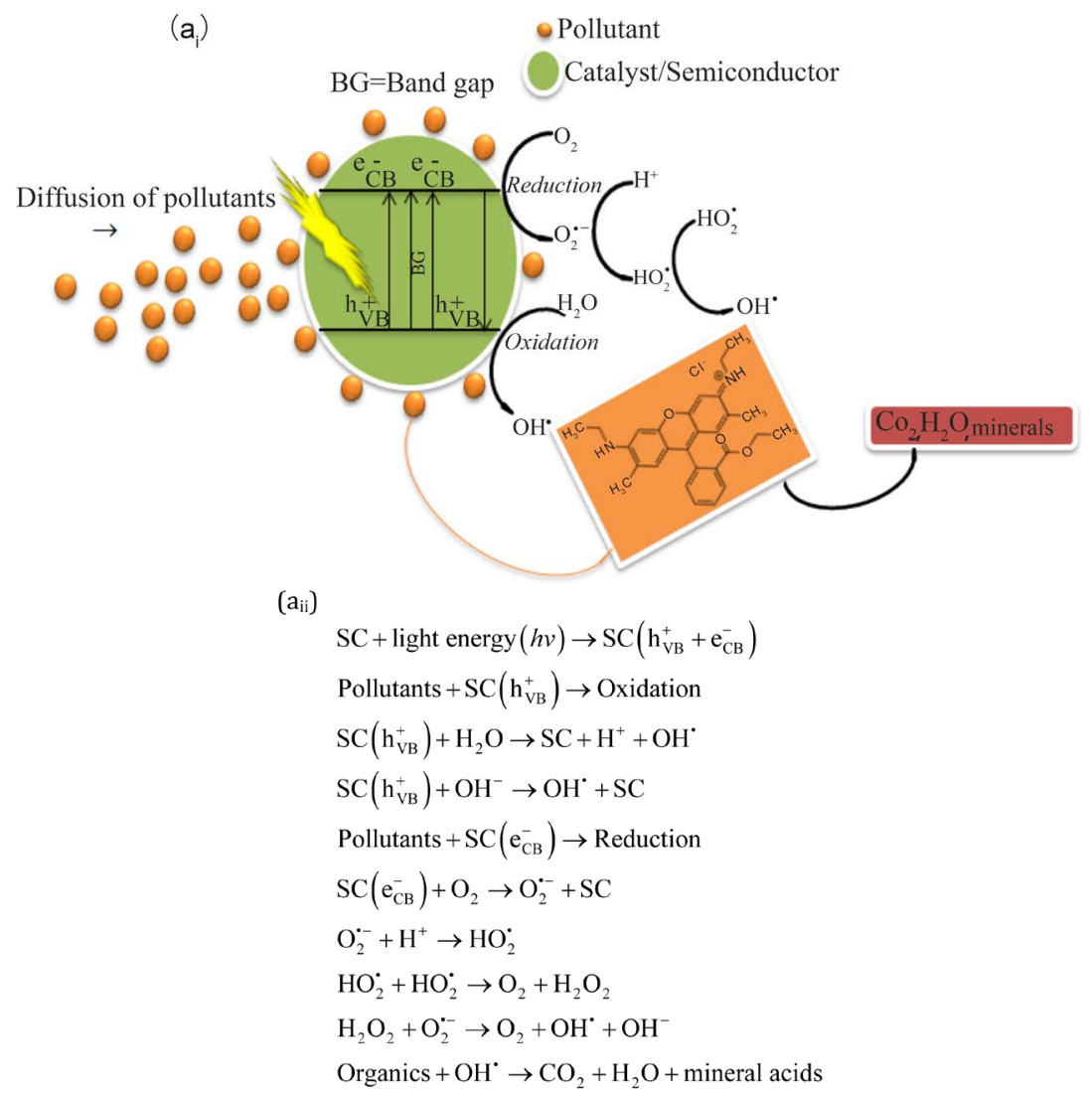

(b)

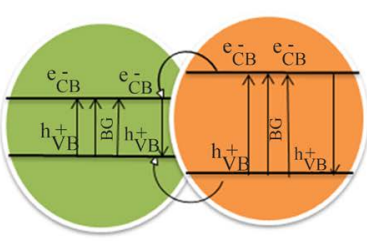

Straddling gap $\left(b_{i i}\right)$

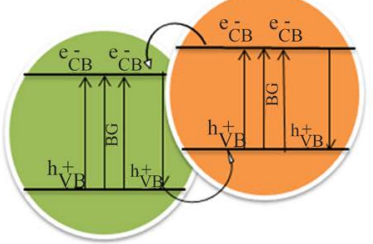

Staggered band

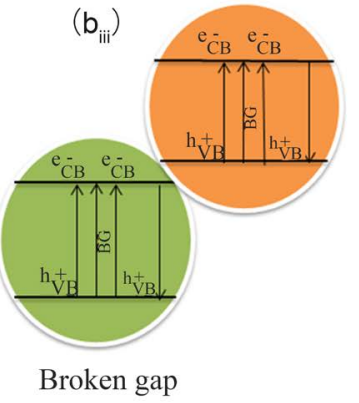

$\left(c_{i}\right)$

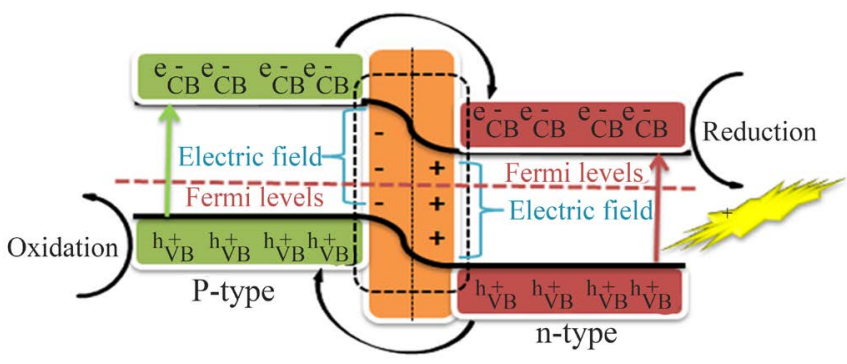

$\left(c_{i i}\right)$

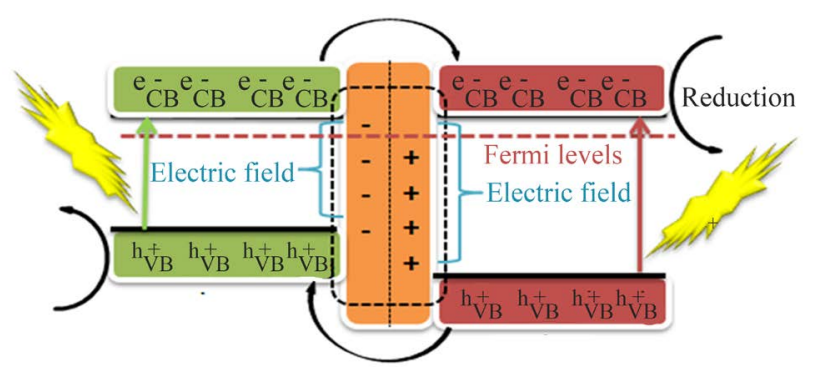




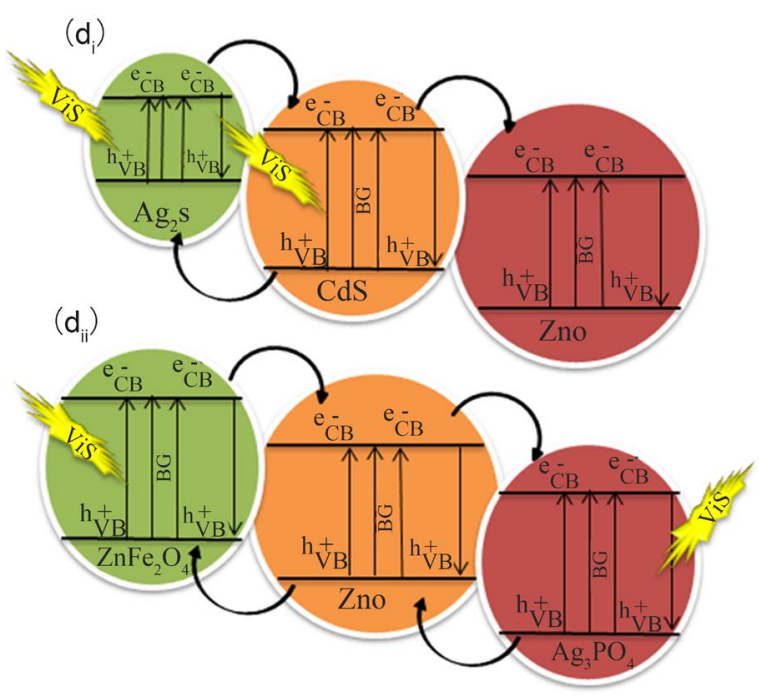

Figure 4. (a) Photocatalysis mechanism and (b) electronic arrangement (c) p-n and n-n heterojunction $(\mathrm{d}) \mathrm{e}^{-} / \mathrm{h}^{+}$separation through band gap engineering of semiconductors.

$\left(\mathrm{H}_{2} \mathrm{O}_{2}\right)$ and hydroxyl radicals $\left(\mathrm{OH}^{*}\right)$. The resulting powerful oxidizing agents $\left(\mathrm{OH}^{*}\right)$ leads to partial or complete mineralization $\left(\mathrm{CO}_{2}, \mathrm{H}_{2} \mathrm{O}\right.$ and mineral acids) of organics pollutants adsorbed on the surface of the semiconductor [119].

Depending on the CB and VB potentials and bandgap energies the electronic arrangement of the semiconductor heterojunctions are categorized into (a) straddling gap (b) staggered gap and (c) broke gap heterojunctions as shown in Figure $4(\mathrm{~b})$. In Figure $4\left(b_{i}\right)$ (straddling gap type) the $\mathrm{e}^{-} / \mathrm{h}^{+}$collected and recombine on shorter band gap semiconductor. Therefore, weakening of the photo catalysis efficiency [120]. In Figure $4\left(b_{\mathrm{ii}}\right)$ (staggered band structure) e-moves to the low negative CB semiconductor and $\mathrm{h}^{+}$transfer to less positive VB of large band gap semiconductor. Here the probability of $\mathrm{e}^{-} / \mathrm{h}^{+}$separation becomes high then the photocatalysis improved [121]. In Figure $4\left(b_{\text {iii }}\right)$ (broken gap heterojunction) due to great variance in the positions of the VB and CB levels, provides higher motive energy to transfer the photo induced charge carriers. Thus, only the staggered gap most typical heterojunction system for photo catalysis purposes [122] and selecting well-matched energy band configuration, less lattice inconformity, and fitting conductivity to be combined with $\mathrm{ZnO}$ has a key for higher photocatalytic activity [31]. To accept $\mathrm{e}^{-}$from $\mathrm{ZnO}$ using semiconductor with positive $\mathrm{CB}$ than $\mathrm{ZnO}$ becomes essential.

The heterojunction composed of an n-type semiconductor as a donor and a $\mathrm{p}$-type semiconductor as an acceptor is so-called $\mathrm{p}-\mathrm{n}$ heterojunction. As shown in (Figure $4\left(c_{\mathrm{i}}\right)$ ) the fermi level $(\mathrm{FL})$ is positioned near the VB in p-type semiconductors place holes constitute major carriers. Moreover in the n-type, the FL is closer to $\mathrm{CB}$ and the concentration of electrons is higher than holes as carriers [123]. Hence, once they come into contact with each other, the FL of p-type shifts to higher and n-type to lower energies until attainment equilibrium level. Consequently, a depletion layer is formed at the interfacial distinct that produces 
an electric field [124]. The resulted electric field from the induction of negative and positive charges on the $\mathrm{p}$ - and $\mathrm{n}$-sides will diffuse the photogenerated electrons and holes out of the depletion layer [125].

Similarly, $\mathrm{n}-\mathrm{n}$ heterojunctions (Figure $\left.4\left(\mathrm{c}_{\mathrm{ii}}\right)\right)$ has been introduced as another slant engaged visible-light-driven (VLD) nice enactment photocatalysts. Like that of $p-n$ type $n-n$ system the fermi levels of both semiconductors should be equilibrium to make a steady and electrostatically balanced system. Subsequently, a depletion layer is created which helps for exploiting visible light and inhibiting the recombination of the photoinduced $\mathrm{e}^{-} / \mathrm{h}^{+}$pairs [126] [127].

Apart from the binary nanocomposites, recently combination of large band gap materials with various semiconductors to develop ternary or multi-component heterostructures resulted in great improvement in photocatalytic performance of photocatalysts under visible-light/solar irradiation. As indicated the studied $\mathrm{ZnO}$ based ternary composites are grouped into four classes, based on: 1) band gap engineering, 2) plasmonic, 3) $\mathrm{p}-\mathrm{n}-\mathrm{n}$ and $\mathrm{n}-\mathrm{n}-\mathrm{n}$ heterojunctions, and 4) magnetic properties.

According to band gap engineering the difference between the energy (CB) of the joint semiconductors forces a rapid transfer of the photoexcited electrons from one semiconductor to other, thus accelerating the separation of $\mathrm{e}^{-} / \mathrm{h}^{+}$pairs and enhancing the photocatalytic efficacy. The enhancement photocatalytic efficacy was confirmed by Chen et al. [12] on $\mathrm{ZnO} / \mathrm{CdS} / \mathrm{Ag}_{2} \mathrm{~S}$ and $\mathrm{Li}$ et al. [13] on $\mathrm{Ag}_{3} \mathrm{PO}_{4} / \mathrm{ZnFe}_{2} \mathrm{O}_{4} / \mathrm{ZnO}$ ternary nanocomposites. The schematic representations for separation of the charge carriers in $\mathrm{ZnO} / \mathrm{CdS} / \mathrm{Ag}_{2} \mathrm{~S}$ and $\mathrm{Ag}_{3} \mathrm{PO}_{4} / \mathrm{ZnFe}_{2} \mathrm{O}_{4} / \mathrm{ZnO}$ nanocomposites are shown in (Figure 4(d)).

The synergistic effects of the internal electric fields formed in the $n-n-n$ or $\mathrm{p}-\mathrm{n}-\mathrm{n}$ heterojunctions between constituents of the ternary nanocomposites are more efficient than the binary $n-n$ or $p-n$ heterojunctions for substantially enhanced separation of the photogenerated $\mathrm{e}^{-} / \mathrm{h}^{+}$pairs and further prolonging lifetime of the charge carriers. Thus, the enhanced photocatalytic performances for the photocatalysts with $n-n-n$ or $p-n-n$ heterojunctions are much more than those of the photocatalysts with n-n or p-n heterojunctions [31].

Now a days since recovering of the engaged photocatalysts from the solution is practically reduce cost and avoids the secondary contamination, especially on large-scale applications, magnetically separable photocatalysts are promising materials. In sight of this, a number of researchers have been investigated $\mathrm{Fe}_{3} \mathrm{O}_{4}$, owing to its outstanding magnetic properties, being environmentally kind and not expensive. Some of ternary composites investigated based on $\mathrm{ZnO}$ and $\mathrm{Fe}_{3} \mathrm{O}_{4}$ includes: $\mathrm{ZnO} / \mathrm{Ag}_{2} \mathrm{O} / \mathrm{Fe}_{3} \mathrm{O}_{4}$ [128], $\mathrm{ZnO} / \mathrm{Ag}_{3} \mathrm{VO}_{4} / \mathrm{Fe}_{3} \mathrm{O}_{4}$ [129], $\mathrm{Fe}_{3} \mathrm{O}_{4} @ \mathrm{AgBr} / \mathrm{ZnO}$ [130], $\mathrm{Fe}_{3} \mathrm{O}_{4} / \mathrm{ZnO} / \mathrm{CoWO}_{4}$ [131], $\mathrm{Fe}_{3} \mathrm{O}_{4} @ \mathrm{ZnO} / \mathrm{AgCl}$ [132], $\mathrm{ZnO} / \mathrm{AgI} / \mathrm{Fe}_{3} \mathrm{O}_{4}$ [133], and $\mathrm{Fe}_{3} \mathrm{O}_{4} / \mathrm{ZnO} / \mathrm{NiWO}_{4}[134]$.

\section{Characterization Techniques}

Different characterization techniques have been practiced for the analysis of 
various physicochemical properties of nanomaterials. Among many characterization techniques, the following are the most important techniques that should be conducted during analysis: 1) Morphological characterizations such as: polarized optical microscopy (POM), transmission electron microscopy (SEM), transmission electron microscopy (TEM), 2) Structural characterizations such as: X-ray diffraction (XRD) [109], energy dispersive X-ray (EDX), X-ray photoelectron spectroscopy (XPS) (surface composition, chemical states, elemental ratio and exact bonding nature), Fourier-transform infrared (FT-IR) Raman, Brunauer-Emmett-Teller (BET) (used for surface area determination) [135], 3) Particle size and surface area characterization such as: SEM, TEM, Dynamic light scattering (DLS), XRD, Atomic force microscopy (AFM) [136], DCS [137], iv. Optical characterizations such as: UV/vis-diffuse reflectance spectrometer (DRS) (for the purpose of absorption, transmittance and reflectance), Photoluminescence (PL) [138].

Finally, beside many industrial and medical applications of those different modified, as well as, un modified nano structured materials, there are certain toxicities which are allied with nanomaterials [139]. Owing to their small size, they can inter easily into the circulatory and lymphatic systems and ultimately to body tissues and organs. Depending on their composition and size, they can harvest irreversible injury to cells by oxidative stress and organelle damage. Nevertheless, the toxicity of nanoparticles depends on various factors, including: size, aggregation, composition, crystallinity, surface functionalization, etc. In addition, their toxicity also determined by the individual's genetic complement, which provides the biochemical toolbox by which it can adapt to and fight toxic substances. The potential adverse health effects associated with inhalation, ingestion and contact with nanoparticles includes: asthma, bronchitis, emphysema, lung cancer, Parkinson's, Alzheimer's, Crohn's, colon cancer, arrhythmia, heart diseases, systemic lupus erythematosus, scleroderma and rheumatoid arthritis. Therefore, basic knowledge and researches is required for these toxic effects to encounter them properly [140].

\section{Conclusion and Future Perspectives}

Before applying the adsorption and photcatalysis techniques for water/wastewater treatment, appropriate understanding on their working mechanisms is essential. Mostly since the Langmuir and Freundlich models fit well with different experimental data, extracting final interpretation depending on only those models became erroneous. In addition, numbers of theoretical explanations have been proposed for PFO and PSO models. However, effective fitting of these models alone is no assurance to predict whether the mechanism of reaction is under control of physical adsorption or chemisorption, as well as, either adsorption-reaction or adsorption-diffusion mechanism. Therefore, applying both adsorption-reaction and adsorption-diffusion mechanism is the key on kinetics of adsorption. In addition, both linear and non-liner fitness of the adsorption data 
should be conducted. On photocatalysis, progress has been done only with simple semiconductors, which is insufficient because of high electron-hole recombination and poor visible light absorption ability. Therefore, modification concerning electron-hole recombination and visible light response got effectiveness on degradation of pollutants. Finally, optimization of different parameters/reaction conditions also ought to be taken into consideration.

\section{Acknowledgements}

Authors acknowledge Adama Science and Technology University (ASTU) for offering financial support.

\section{Conflicts of Interest}

The authors declare no conflicts of interest regarding the publication of this paper.

\section{References}

[1] Ali, R.M., Hamad, H.A., Hussein, M.M. and Malash, G.F. (2016) Potential of Using Green Adsorbent of Heavy Metal Removal from Aqueous Solutions: Adsorption Kinetics, Isotherm, Thermodynamic, Mechanism and Economic Analysis. Ecological Engineering, 91, 317-332. https://doi.org/10.1016/j.ecoleng.2016.03.015

[2] Wong, S., Ngadi, N., Inuwa, I.M. and Hassan, O. (2018) Recent Advances in Applications of Activated Carbon from Bio-Waste for Wastewater Treatment: A Short Review. Journal of Cleaner Production, 175, 361-375. https://doi.org/10.1016/j.jclepro.2017.12.059

[3] Kyzas, G.Z., Kostoglou, M., Lazaridis, N.K., Lambropoulou, D.A. and Bikiaris, D.N. (2013) Environmental Friendly Technology for the Removal of Pharmaceutical Contaminants from Wastewaters Using Modified Chitosan Adsorbents. Chemical Engineering Journal, 222, 248-258. https://doi.org/10.1016/j.cej.2013.02.048

[4] Yin, J., Deng, C., Yu, Z., Wang, X. and Xu, G. (2018) Effective Removal of Lead Ions from Aqueous Solution Using Nano Illite/Smectite Clay: Isotherm, Kinetic and Thermodynamic Modeling of Adsorption. Water, 10, 210.

https://doi.org/10.3390/w10020210

[5] Gomez-solís, C., Ballesteros, J.C., Torres-martínez, L.M., Juárez-ramírez, I., Torres, L.A.D., Zarazua-morin, M.E. and Whon, S. (2015) Rapid Synthesis of ZnO Nano-Corncobs from Nital Solution and Its Application in the Photodegradation of Methyl Orange. Journal of Photochemistry \& Photobiology A: Chemistry, 298, 49-54. https://doi.org/10.1016/j.jphotochem.2014.10.012

[6] Moradi, S., Aberoomand-azar, P. and Raeis-farshid, S. (2016) The Effect of Different Molar Ratios of $\mathrm{ZnO}$ on Characterization and Photocatalytic Activity of $\mathrm{TiO}_{2} / \mathrm{ZnO}$ Nanocomposite. Journal of Saudi Chemical Society, 20, 373-378. https://doi.org/10.1016/j.jscs.2012.08.002

[7] Chiang, Y. and Lin, C. (2013) Photocatalytic Decolorization of Methylene Blue in Aqueous Solutions Using Coupled $\mathrm{ZnO} / \mathrm{SnO}_{2}$ Photocatalysts. Powder Technology, 246, 137-143. https://doi.org/10.1016/j.powtec.2013.04.033

[8] Yang, G., Yan, Z. and Xiao, T. (2012) Preparation and Characterization of $\mathrm{SnO}_{2} / \mathrm{ZnO} / \mathrm{TiO}_{2}$ Composite Semiconductor with Enhanced Photocatalytic Activity. Applied Surface Science, 258, 8704-8712. https://doi.org/10.1016/j.apsusc.2012.05.078 
[9] Zno, O., Saravanan, R., Gupta, V.K., Narayanan, V. and Stephen, A. (2014) Visible Light Degradation of Textile Effluent Using Novel Catalyst. Journal of the Taiwan Institute of Chemical Engineers, 45, 1910-1917. https://doi.org/10.1016/j.jtice.2013.12.021

[10] Qamar, M.T., Aslam, M., Rehan, Z.A., Soomro, M.T., Basahi, J.M., Ismail, I.M. I., et al. (2017) The Influence of P-Type $\mathrm{Mn}_{3} \mathrm{O}_{4}$ Nanostructures on the Photocatalytic Activity of $\mathrm{ZnO}$ for the Removal of Bromo and Chlorophenol in Natural Sunlight Exposure. Applied Catalysis B, Environmental, 201, 105-118.

https://doi.org/10.1016/j.apcatb.2016.08.004

[11] Vahid Hoseinpour, N.G. (2018) Novel $\mathrm{ZnO}-\mathrm{MnO}_{2}-\mathrm{Cu}_{2} \mathrm{O}$ Triple Nanocomposite: Facial Synthesis, Characterization, Antibacterial Activity and Visible Light Photocatalytic Performance for Dyes Degradation: A Comparative Study. Materials Research Express.

[12] Chen, C.H., Li, Z.C., Lin, H.N., Wang, G.J., Liao, J.C. and Shasha Lv, W.L. (2016) Enhanced Visible Light Photocatalytic Performance of $\mathrm{ZnO}$ Nanowires Integrated with CdS and $\mathrm{Ag}_{2} \mathrm{~S}$. Dalton Transactions, No. 9. https://doi.org/10.1039/C5DT04533A

[13] Li, J., Liu, Z. and Zhu, Z. (2015) Enhanced Photocatalytic Activity in $\mathrm{ZnFe}_{2} \mathrm{O}_{4}-\mathrm{ZnO}-\mathrm{Ag}_{3} \mathrm{PO}_{4}$ Hollow Nanospheres through the Cascadal Electron Transfer with Magnetical Separation. Journal of Alloys and Compounds Journal, 636, 229-233. https://doi.org/10.1016/j.jallcom.2015.02.176

[14] Liu, Y., Zhu, G., Chen, J., Xu, H., Shen, X. and Yuan, A. (2013) $\mathrm{Co}_{3} \mathrm{O}_{4} / \mathrm{ZnO}$ Nanocomposites for Gas-Sensing Applications. Applied Surface Science, 265, 379-384. https://doi.org/10.1016/j.apsusc.2012.11.016

[15] Wang, C., Tan, X., Yan, J., Chai, B., Li, J. and Chen, S. (2017) Electrospinning Direct Synthesis of Magnetic $\mathrm{ZnFe}_{2} \mathrm{O}_{4} / \mathrm{ZnO}$ Multi-Porous Nanotubes with Enhanced Photocatalytic Activity. Applied Surface Science, 396, 780-790. https://doi.org/10.1016/j.apsusc.2016.11.029

[16] Li, Y., Li, Y., Yin, Y., Xia, D., Ding, H., Ding, C. and Wu, J. (2018) Facile Synthesis of Highly Efficient $\mathrm{ZnO} / \mathrm{ZnFe}_{2} \mathrm{O}_{4}$ Photocatalyst Using Earth-Abundant Sphalerite and Its Visible Light Photocatalytic Activity. Applied Catalysis B: Environmental, 226, 324-336. https://doi.org/10.1016/j.apcatb.2017.12.051

[17] Davari, N., Farhadian, M., Reza, A., Nazar, S. and Homayoonfal, M. (2017) Degradation of Diphenhydramine by the Photocatalysts of $\mathrm{ZnO} / \mathrm{Fe}_{2} \mathrm{O}_{3}$ and $\mathrm{TiO}_{2} / \mathrm{Fe}_{2} \mathrm{O}_{3}$ Based on Clinoptilolite: Structural and Operational Comparison. Journal of Environmental Chemical Engineering, 5, 5707-5720. https://doi.org/10.1016/j.jece.2017.10.052

[18] Saito, F. (2008) Improvement in Photocatalytic Activity of $\mathrm{TiO}_{2}$ under Visible Irradiation through Addition of $\mathrm{N}^{-\mathrm{TiO}_{2}}$. Environmental Science \& Technology, 42, 3622-3626. https://doi.org/10.1021/es702932m

[19] Zno, N., Qin, H., Li, W., Xia, Y. and He, T. (2011) Photocatalytic Activity of Heterostructures Based on $\mathrm{ZnO}$ and N-Doped ZnO. American Chemical Society, 3, 3152-3156.

[20] Lin, L., Kavadiya, S., Begum, B., Nie, Y., Raliya, R., Wang, S.T., et al. (2018) $\mathrm{ZnO}_{1-x} /$ Carbon Dots Composite Hollow Spheres: Facile Aerosol Synthesis and Superior $\mathrm{CO}_{2}$ Photoreduction under UV, Visible and Near-Infrared Irradiation. Applied Catalysis B: Environmental, 230, 36-48. https://doi.org/10.1016/j.apcatb.2018.02.018

[21] Li, X., Yu, J. and Jaroniec, M. (2016) Hierarchical Photocatalysts. Chemical Society 
Reviews, 45, 2603-2636. https://doi.org/10.1039/C5CS00838G

[22] Sathishkumar, P., Sweena, R., Wu, J.J. and Anandan, S. (2011) Synthesis of CuO-ZnO Nanophotocatalyst for Visible Light Assisted Degradation of a Textile Dye in Aqueous Solution. Chemical Engineering Journal, 171, 136-140.

https://doi.org/10.1016/j.cej.2011.03.074

[23] Habibi, M.H. and Karimi, B. (2014) Application of Impregnation Combustion Method for Fabrication of Nanostructure $\mathrm{CuO} / \mathrm{ZnO}$ Composite Oxide: XRD, FESEM, DRS and FTIR Study. Journal of Industrial and Engineering Chemistry, 20, 1566-1570. https://doi.org/10.1016/j.jiec.2013.07.048

[24] Liao, W., Zheng, T., Wang, P., Tu, S. and Pan, W. (2010) Efficient Microwave-Assisted Photocatalytic Degradation of Endocrine Disruptor Dimethyl Phthalate over Composite Catalyst $\mathrm{ZrO}_{x} / \mathrm{ZnO}$. Journal of Environmental Sciences, 22, 1800-1806. https://doi.org/10.1016/S1001-0742(09)60322-3

[25] Ciciliati, M.A., Silva, M.F., Fernandes, D.M., De Melo, M.A.C., Adelina, A., Hechenleitner, W. and Pineda, E.A.G. (2015) Fe-Doped ZnO Nanoparticles: Synthesis by a Modified Sol-Gel Method and Characterization. Materials Letters, 159, 84-86. https://doi.org/10.1016/j.matlet.2015.06.023

[26] Margan, P. and Haghighi, M. (2018) Sono-Coprecipitation Synthesis and Physicochemical Characterization of CdO-ZnO Nanophotocatalyst for Removal of Acid Orange 7 from Wastewater. Ultrasonics Sonochemistry, 40, 323-332. https://doi.org/10.1016/j.ultsonch.2017.07.003

[27] Zare, M., Namratha, K., Thakur, M.S., Yallappa, S. and Byrappa, K. (2018) Comprehensive Biological Assessment and Photocatalytic Activity of Surfactant Assisted Solvothermal Synthesis of ZnO Nanogranules. Materials Chemistry and Physics, 215, 148-156. https://doi.org/10.1016/j.matchemphys.2018.04.109

[28] Yang, H., Zhang, Q., Chen, Y., Huang, Y., Yang, F. and Lu, Z. (2018) Ultrasonic-Microwave Synthesis of $\mathrm{ZnO} / \mathrm{BiOBr}$ Functionalized Cotton Fabrics with Antibacterial and Photocatalytic Properties. Carbohydrate Polymers, 201, 162-171. https://doi.org/10.1016/j.carbpol.2018.08.068

[29] Osman, A. and Akbulut, H. (2015) A Facile Synthesis of Zinc Oxide/Multiwalled Carbon Nanotube Nanocomposite Lithium Ion Battery Anodes by Sol-Gel Method. Journal of Power Sources, 295, 235-245. https://doi.org/10.1016/j.jpowsour.2015.06.135

[30] Boon, C., Yong, L. and Wahab, A. (2018) A Review of ZnO Nanoparticles as Solar Photocatalysts: Synthesis, Mechanisms and Applications. Renewable and Sustainable Energy Reviews, 81, 536-551. https://doi.org/10.1016/j.rser.2017.08.020

[31] Pirhashemi, M., Habibi-Yangjeh, A. and Pouran, S.R. (2018) Review on the Criteria Anticipated for the Fabrication of Highly Efficient ZnO-Based Visible-Light-Driven Photocatalysts. Journal of Industrial and Engineering Chemistry, 62, 1-25. https://doi.org/10.1016/j.jiec.2018.01.012

[32] Krishnakumar, B., Selvam, K., Velmurugan, R. and Swaminathan, M. (2010) Influence of Operational Parameters on Photodegradation of Acid Black 1 with $\mathrm{ZnO}$. Desalination and Water Treatment, 24, 132-139. https://doi.org/10.5004/dwt.2010.1466

[33] Hazime, R., Nguyen, Q.H., Ferronato, C., Salvador, A., Jaber, F. and Chovelon, J.-M. (2014) Comparative Study of Imazalil Degradation in Three Systems: $\mathrm{UV} / \mathrm{TiO}_{2}, \mathrm{UV} / \mathrm{K}_{2} \mathrm{~S}_{2} \mathrm{O}_{8}$ and $\mathrm{UV} / \mathrm{TiO}_{2} / \mathrm{K}_{2} \mathrm{~S}_{2} \mathrm{O}_{8}$. Applied Catalysis B: Environmental, 144, 286-291. https://doi.org/10.1016/j.apcatb.2013.07.001

[34] Daneshvar, N. and Aber, S. (2009) Influence of Inorganic Oxidants and Metal Ions 
on Photocatalytic Activity of Prepared Zinc Oxide Nanocrystals. Global NEST Journal, 11, 535-545.

[35] Tan, K.L. and Hameed, B.H. (2017) Insight into the Adsorption Kinetics Models for the Removal of Contaminants from Aqueous Solutions. Journal of the Taiwan Institute of Chemical Engineers, 74, 25-48. https://doi.org/10.1016/j.jtice.2017.01.024

[36] Plazinski, W., Rudzinski, W., Plazinska, A. (2009) Theoretical Models of Sorption Kinetics Including a Surface Reaction Mechanism: A Review. Advances in Colloid and Interface Science, 152, 2-13. https://doi.org/10.1016/j.cis.2009.07.009

[37] Zhang, W., Zhang, S., Wang, J., Wang, M., He, Q., Song, J., et al. (2018) Hybrid Functionalized Chitosan- $\mathrm{Al}_{2} \mathrm{O}_{3} @ \mathrm{SiO}_{2}$ Composite for Enhanced $\mathrm{Cr}(\mathrm{VI})$ Adsorption. Chemosphere, 203, 188-198. https://doi.org/10.1016/j.chemosphere.2018.03.188

[38] Mittal, A., Gajbe, V. and Mittal, J. (2008) Removal and Recovery of Hazardous Triphenylmethane Dye, Methyl Violet through Adsorption over Granulated Waste Materials. Journal of Hazardous Materials, 150, 364-375. https://doi.org/10.1016/j.jhazmat.2007.04.117

[39] Kalavathy, M.H., Karthikeyan, T., Rajgopal, S. and Miranda, L.R. (2005) Kinetic and Isotherm Studies of $\mathrm{Cu}(\mathrm{II})$ Adsorption onto $\mathrm{H}_{3} \mathrm{PO}_{4}$-Activated Rubber Wood Sawdust. Journal of Colloid and Interface Science, 292, 354-362. https://doi.org/10.1016/j.jcis.2005.05.087

[40] Tan, I.A.W., Ahmad, A.L. and Hameed, B.H. (2009) Adsorption Isotherms, Kinetics, Thermodynamics and Desorption Studies of 2,4,6-Trichlorophenol on Oil Palm Empty Fruit Bunch-Based Activated Carbon. Journal of Hazardous Materials, 164, 473-482. https://doi.org/10.1016/j.jhazmat.2008.08.025

[41] Lin, C.I. and Wang, L.H. (2008) Rate Equations and Isotherms for Two Adsorption Models. Journal of the Chinese Institute of Chemical Engineers, 39, 579-585. https://doi.org/10.1016/j.jcice.2008.04.003

[42] Crini, G. and Lichtfouse, E. (2017) Green Adsorbents for Pollutant Removal. Environmental Chemistry for a Sustainable World. https://doi.org/10.1007/978-3-319-92162-4

[43] Zhou, L., Pan, S., Chen, X., Zhao, Y., Zou, B. and Jin, M. (2014) Kinetics and Thermodynamics Studies of Pentachlorophenol Adsorption on Covalently Functionalized $\mathrm{Fe}_{3} \mathrm{O}_{4} @ \mathrm{SiO}_{2}-\mathrm{MWCNTs}$ Core-Shell Magnetic Microspheres. Chemical Engineering Journal, 257, 10-19. https://doi.org/10.1016/j.cej.2014.07.060

[44] Brunauer, S., Emmett, P.H. and Teller, E. (1936) Adsorption of Gases in Multimolecular Layers. Journal of the American Chemical Society, 1938, 309-319.

[45] Dada, A.O., Olalekan, A.P., Olatunya, A.M. and Dada, O. (2012) Langmuir, Freundlich, Temkin and Dubinin-Radushkevich Isotherms Studies of Equilibrium Sorption of $\mathrm{Zn}^{2+}$ Unto Phosphoric Acid Modified Rice Husk. IOSR Journal of Applied Chemistry, 3, 38-45.

[46] Ebelegi, A., Ayawei, N., Ebelegi, A.N. and Wankasi, D. (2017) Modelling and Interpretation of Adsorption Isotherms. Journal of Chemistry, 2017, Article ID: 3039817.

[47] Hamdaoui, O. and Naffrechoux, E. (2007) Modeling of Adsorption Isotherms of Phenol and Chlorophenols onto Granular Activated Carbon. Part I. Two-Parameter Models and Equations Allowing Determination of Thermodynamic Parameters. Journal of Hazardous Materials, 147, 381-394. https://doi.org/10.1016/j.jhazmat.2007.01.021

[48] Chung, H.K., Kim, W.H., Park, J., Cho, J., Jeong, T.Y. and Park, P.K. (2015) Application of Langmuir and Freundlich Isotherms to Predict Adsorbate Removal Effi- 
ciency or Required Amount of Adsorbent. Journal of Industrial and Engineering Chemistry, 28, 241-246. https://doi.org/10.1016/j.jiec.2015.02.021

[49] Jeppu, G.P. and Clement, T.P. (2012) A Modified Langmuir-Freundlich Isotherm Model for Simulating $\mathrm{pH}-$ Dependent Adsorption Effects. Journal of Contaminant Hydrology, 129-130, 46-53. https://doi.org/10.1016/j.jconhyd.2011.12.001

[50] Siyasukh, A., Chimupala, Y. and Tonanon, N. (2018) Preparation of Magnetic Hierarchical Porous Carbon Spheres with Graphitic Features for High Methyl Orange Adsorption Capacity. Carbon, 134, 207-221. https://doi.org/10.1016/j.carbon.2018.03.093

[51] Nechifor, G., Pascu, D., Neagu, M.P., Traistaru, G.A. and Albu, P.C. (2015) Comparative Study of Temkin and Flory-Huggins Isotherms for Adsorption of Phosphate Anion on Membranes. UPB Scientific Bulletin, 77, 63-72

[52] Vijayaraghavan, K., Padmesh, T.V.N., Palanivelu, K. and Velan, M. (2006) Biosorption of Nickel(II) Ions onto Sargassum wightii: Application of Two-Parameter and Three-Parameter Isotherm Models. Journal of Hazardous Materials, 133, 304-308. https://doi.org/10.1016/j.jhazmat.2005.10.016

[53] Ceylan, Z., Mustafaoglu, D. and Malkoc, E. (2018) Adsorption of Phenol by MMT-CTAB and WPT-CTAB: Equilibrium, Kinetic, and Thermodynamic Study. Particulate Science and Technology, 36, 716-726.

[54] Dolić, S.D., Jovanović, D.J., Smits, K., Babić, B., Marinović-Cincović, M., Porobić, S., et al. (2018) A Comparative Study of Photocatalytically Active Nanocrystalline Tetragonal Zyrcon-Type and Monoclinic Scheelite-Type Bismuth Vanadate. Ceramics International, 44, 17953-17961. https://doi.org/10.1016/j.ceramint.2018.06.272

[55] Kalhor, M.M., Rafati, A.A., Rafati, L. and Rafati, A.A. (2018) Synthesis, Characterization and Adsorption Studies of Amino Functionalized Silica Nano Hollow Sphere as an Efficient Adsorbent for Removal of Imidacloprid Pesticide. Journal of Molecular Liquids, 266, 453-459. https://doi.org/10.1016/j.molliq.2018.06.041

[56] El-Said, G.F., El-Sadaawy, M.M. and Aly-Eldeen, M.A. (2018) Adsorption Isotherms and Kinetic Studies for the Defluoridation from Aqueous Solution Using Eco-Friendly Raw Marine Green Algae, Ulva lactuca. Environmental Monitoring and Assessment, 190, 14.

[57] Sya, A., Salmiati, S., Jonbi, J. and Ali, M. (2018) Application of the Kinetic and Isotherm Models for Better Understanding of the Behaviors of Silver Nanoparticles Adsorption onto Different Adsorbents. Journal of Environmental Management, 218, 59-70. https://doi.org/10.1016/j.jenvman.2018.03.066

[58] Rafati, L., Ehrampoush, M.H., Rafati, A.A., Mokhtari, M. and Mahvi, A.H. (2018) Removal of Ibuprofen from Aqueous Solution by Functionalized Strong Nano-Clay Composite Adsorbent: Kinetic and Equilibrium Isotherm Studies. International Journal of Environmental Science and Technology, 15, 513-524. https://doi.org/10.1007/s13762-017-1393-0

[59] Liu, X., Wu, H., Hu, T. and Chen, X. (2018) Adsorption and Leaching of Novel Fungicide Pyraoxystrobin on Soils by ${ }^{14} \mathrm{C}$ Tracing Method. Environmental Monitoring and Assessment, 190, 86. https://doi.org/10.1007/s10661-017-6458-5

[60] Zarei, S., Niad, M. and Raanaei, H. (2018) The Removal of Mercury Ion Pollution by Using $\mathrm{Fe}_{3} \mathrm{O}_{4}$-Nanocellulose: Synthesis, Characterizations and DFT Studies. Journal of Hazardous Materials, 344, 258-273.

https://doi.org/10.1016/j.jhazmat.2017.10.009

[61] Inglezakis, V.J. and Zorpas, A.A. (2012) Heat of Adsorption, Adsorption Energy 
and Activation Energy in Adsorption and Ion Exchange Systems. Desalination and Water Treatment, 39, 149-157. https://doi.org/10.1080/19443994.2012.669169

[62] Douven, S., Paez, C.A. and Gommes, C.J. (2015) The Range of Validity of Sorption Kinetic Models. Journal of Colloid and Interface Science, 448, 437-450. https://doi.org/10.1016/j.jcis.2015.02.053

[63] Üner, O., Geçgel, Ü., Kolancilar, H. and Bayrak, Y. (2017) Adsorptive Removal of Rhodamine B with Activated Carbon Obtained from Okra Wastes. Chemical Engineering Communications, 204, 772-783. https://doi.org/10.1080/00986445.2017.1319361

[64] Accardo, J.V. and Kalow, J.A. (2018) Reversibly Tuning Hydrogel Stiffness through Photocontrolled Dynamic Covalent Crosslinks. Chemical Science, 9, 5987-5993. https://doi.org/10.1039/C8SC02093K

[65] Shen, W., Zhang, C., Zhang, L., Xu, Q., Cui, Y. and Xu, Y.A (2018) A Modified Avrami Equation for Kinetics of Static Recrystallization of Nb-V Microalloyed Steel: Experiments and Numerical Simulation. Vacuum, 150, 116-123. https://doi.org/10.1016/j.vacuum.2018.01.022

[66] Xiao, Y., Azaiez, J. and Hill, J.M. (2018) Erroneous Application of Pseudo-Second-Order Adsorption Kinetics Model: Ignored Assumptions and Spurious Correlations. Industrial \& Engineering Chemistry Research, 57, 2705-2709.

[67] Liu, Y., Lan, J., Zhao, Y., Yuan, L., Li, Z., Yuan, Y., et al. (2012) A High Efficient Sorption of U(VI) from Aqueous Solution Using Amino-Functionalized SBA-15. Journal of Radio analytical and Nuclear Chemistry, 291, 803-810. https://doi.org/10.1007/s10967-011-1515-y

[68] Sun, P., Hui, C., Azim Khan, R., Du, J., Zhang, Q. and Zhao, Y.H. (2015) Efficient Removal of Crystal Violet Using $\mathrm{Fe}_{3} \mathrm{O}_{4}$-Coated Biochar: The Role of the $\mathrm{Fe}_{3} \mathrm{O}_{4} \mathrm{Na}$ noparticles and Modeling Study Their Adsorption Behavior. Scientific Reports, 5, Article No. 12638. https://doi.org/10.1038/srep12638

[69] Xin, X., Wei, Q., Yang, J., Yan, L., Feng, R., Chen, G., et al. (2012) Highly Efficient Removal of Heavy Metal Ions by Amine-Functionalized Mesoporous $\mathrm{Fe}_{3} \mathrm{O}_{4}$ Nanoparticles. Chemical Engineering Journal, 184, 132-140. https://doi.org/10.1016/j.cej.2012.01.016

[70] John Babu, D., King, P. and Prasanna Kumar, Y. (2018) Optimization of Cu(II) Biosorption onto Sea Urchin Test Using Response Surface Methodology and Artificial Neural Networks. International Journal of Environmental Science and Technology, 1-12.

[71] Haerifar, M. and Azizian, S. (2013) Mixed Surface Reaction and Diffusion-Controlled Kinetic Model for Adsorption at the Solid/Solution Interface. The Journal of Physical Chemistry C, 117, 8310-8317.

[72] Erhayem, M., Al-tohami, F., Mohamed, R. and Ahmida, K. (2015) Isotherm, Kinetic and Thermodynamic Studies for the Sorption of Mercury(II) onto Activated Carbon from Rosmarinus officinalis Leaves. American Journal of Analytical Chemistry, 6, 1-10. https://doi.org/10.4236/ajac.2015.61001

[73] Rao, P., Sun, Z., Zhang, W., Yao, W., Wang, L. and Ding, G. (2015) Preparation and Application of Amorphous Fe-Ti Bimetal Oxides for Arsenic Removal. RSC Advances, 5, 89545-89551. https://doi.org/10.1039/C5RA12039J

[74] Mandal, A. and Singh, N. (2016) Kinetic and Isotherm Error Optimization Studies for Adsorption of Atrazine and Imidacloprid on Bark of Eucalyptus tereticornis L. Journal of Environmental Science and Health, Part B, 51, 192-203. https://doi.org/10.1080/03601234.2015.1108817 
[75] Amin, M.T., Alazba, A.A. and Shafiq, M. (2015) Adsorptive Removal of Reactive Black 5 from Wastewater Using Bentonite Clay: Isotherms, Kinetics and Thermodynamics. Sustainability, 7, 15302-15318. https://doi.org/10.3390/su71115302

[76] Inyinbor, A.A., Adekola, F.A. and Olatunji, G.A. (2016) Kinetics, Isotherms and Thermodynamic Modeling of Liquid Phase Adsorption of Rhodamine B Dye onto Raphia hookerie Fruit Epicarp. Water Resources and Industry, 15, 14-27. https://doi.org/10.1016/j.wri.2016.06.001

[77] Aljeboree, A.M., Alshirifi, A.N. and Alkaim, A.F. (2017) Kinetics and Equilibrium Study for the Adsorption of Textile Dyes on Coconut Shell Activated Carbon. Arabian Journal of Chemistry, 10, 3381-3393. https://doi.org/10.1016/j.arabjc.2014.01.020

[78] Moussout, H., Ahlafi, H., Aazza, M. and Maghat, H. (2018) Critical of Linear and Nonlinear Equations of Pseudo-First Order and Pseudo-Second Order Kinetic Models. Karbala International Journal of Modern Science, 4, 244-254. https://doi.org/10.1016/j.kijoms.2018.04.001

[79] Mrhar, O.A., Assali, H.N. and Lyoubi, M.S.E. (2015) Application of Nonlinear Regression Analysis to Select the Optimum Absorption Isotherm for Methylene Blue Adsorption onto Natural Illitic Clay. Bulletin de la Société Royale des Sciences de Liège, 84, 116-130.

[80] Han, R., Wang, Y., Zou, W., Wang, Y. and Shi, J. (2007) Comparison of Linear and Nonlinear Analysis in Estimating the Thomas Model Parameters for Methylene Blue Adsorption onto Natural Zeolite in Fixed-Bed Column. Journal of Hazardous Materials, 145, 331-335. https://doi.org/10.1016/j.jhazmat.2006.12.027

[81] Khanday, W.A., Marrakchi, F., Asif, M. and Hameed, B.H. (2017) Mesoporous Zeolite-Activated Carbon Composite from Oil Palm Ash as an Effective Adsorbent for Methylene Blue. Journal of the Taiwan Institute of Chemical Engineers, 70, 32-41. https://doi.org/10.1016/j.jtice.2016.10.029

[82] Kumar, K.V. and Sivanesan, S. (2006) Pseudo Second Order Kinetics and Pseudo Isotherms for Malachite Green onto Activated Carbon: Comparison of Linear and Non-Linear Regression Methods. Journal of Hazardous Materials, 136, 721-726. https://doi.org/10.1016/j.jhazmat.2006.01.003

[83] Ng, J.C.Y., Cheung, W.H. and McKay, G. (2002) Equilibrium Studies of the Sorption of $\mathrm{Cu}(\mathrm{II})$ Ions onto Chitosan. Journal of Colloid and Interface Science, 255, 64-74. https://doi.org/10.1006/jcis.2002.8664

[84] Foo, K.Y. and Hameed, B.H. (2010) Insights into the Modeling of Adsorption Isotherm Systems. Chemical Engineering Journal, 156, 2-10. https://doi.org/10.1016/j.cej.2009.09.013

[85] Chen, X. (2015) Modeling of Experimental Adsorption Isotherm Data. Information, 6, 14-22. https://doi.org/10.3390/info6010014

[86] Guo, H., Lin, K., Zheng, Z., Xiao, F. and Li, S. (2012) Sulfanilic Acid-Modified P25 $\mathrm{TiO}_{2}$ Nanoparticles with Improved Photocatalytic Degradation on Congo Red under Visible Light. Dyes and Pigments, 92, 1278-1284. https://doi.org/10.1016/j.dyepig.2011.09.004

[87] Vinu, R. and Madras, G. (2010) Environmental Remediation by Photocatalysis. Journal of the Indian Institute of Science, 90, 189-230

[88] Janotti, A. and Van de Walle, C.G. (2009) Fundamentals of Zinc Oxide as a Semiconductor. Reports on Progress in Physics, 72, Article ID: 126501.

[89] Madhusudhana, N., Yogendra, K., Mahadevan, K.M. and Cao, K. (2012) A Com- 
parative Study on Photocatalytic Degradation of Violet $\mathrm{GL}_{2} \mathrm{~B}$ Azo Dye Using $\mathrm{CaO}$ and $\mathrm{TiO}_{2}$ Nanoparticles. International Journal of Engineering Research and Applications, 2, 1300-1307.

[90] Song, M.X., Bian, L., Zhou, T.L. and Zhao, X.Y. (2008) Surface $\zeta$ Potential and Photocatalytic Activity of Rare Earths Doped $\mathrm{TiO}_{2}$. Journal of Rare Earths, 26, 693-699. https://doi.org/10.1016/S1002-0721(08)60165-9

[91] Wang, D., Wang, Y., Li, X., Luo, Q., An, J. and Yue, J. (2008) Sunlight Photocatalytic Activity of Polypyrrole- $\mathrm{TiO}_{2}$ Nanocomposites Prepared by "in Situ" Method. Catalysis Communications, 9, 1162-1166. https://doi.org/10.1016/j.catcom.2007.10.027

[92] Macák, J.M., Tsuchiya, H., Ghicov, A. and Schmuki, P. (2005) Dye-Sensitized Anodic $\mathrm{TiO}_{2}$ Nanotubes. Electrochemistry Communications, 7, 1133-1137. https://doi.org/10.1016/j.elecom.2005.08.013

[93] An, H., Zhou, J., Li, J., Zhu, B., Wang, S., Zhang, S., et al. (2009) Deposition of Pt on the Stable Nanotubular $\mathrm{TiO}_{2}$ and Its Photocatalytic Performance. Catalysis Communications, 11, 175-179. https://doi.org/10.1016/j.catcom.2009.09.020

[94] Wang, X., Zhang, S., Peng, B., Wang, H., Yu, H. and Peng, F. (2016) Enhancing the Photocatalytic Efficiency of $\mathrm{TiO}_{2}$ Nanotube Arrays for $\mathrm{H}_{2}$ Production by Using Non-Noble Metal Cobalt as Co-Catalyst. Materials Letters, 165, 37-40. https://doi.org/10.1016/j.matlet.2015.11.103

[95] Wen, J., Li, X., Liu, W., Fang, Y., Xie, J. and Xu, Y. (2015) Photocatalysis Fundamentals and Surface Modification of $\mathrm{TiO}_{2}$ Nanomaterials. Chinese Journal of Catalysis, 36, 2049-2070. https://doi.org/10.1016/S1872-2067(15)60999-8

[96] Kumar, S.G. and Rao, K.S.R.K. (2017) Comparison of Modification Strategies towards Enhanced Charge Carrier Separation and Photocatalytic Degradation Activity of Metal Oxide Semiconductors $\left(\mathrm{TiO}_{2}, \mathrm{WO}_{3}\right.$ and $\left.\mathrm{ZnO}\right)$. Applied Surface Science, 391, 124-148. https://doi.org/10.1016/j.apsusc.2016.07.081

[97] Qian, S., Wang, C., Liu, W., Zhu, Y., Yao W. and Lu, X. (2011) An Enhanced $\mathrm{CdS} / \mathrm{TiO}_{2}$ Photocatalyst with High Stability and Activity: Effect of Mesoporous Substrate and Bifunctional Linking Molecule. Journal of Material Chemistry, 21, 4945-4952. https://doi.org/10.1039/c0jm03508d

[98] Zhang, D. (2010) Synthesis and Characterization of ZnO-Doped Cupric Oxides and Evaluation of Their Photocatalytic Performance under Visible Light. Transition Metal Chemistry, 35, 689-694. https://doi.org/10.1007/s11243-010-9380-z

[99] Zhang, D. and Zeng, F. (2010) Structural, Photochemical and Photocatalytic Properties of Zirconium Oxide Doped $\mathrm{TiO}_{2}$ Nanocrystallites. Applied Surface Science, 257, 867-871. https://doi.org/10.1016/j.apsusc.2010.07.083

[100] Lin, C. and Chiang, Y. (2012) Preparation of Coupled $\mathrm{ZnO} / \mathrm{SnO}_{2}$ Photocatalysts Using a Rotating Packed Bed. Chemical Engineering Journal, 181-182, 196-205. https://doi.org/10.1016/j.cej.2011.11.062

[101] Hayat, K., Gondal, M.A., Khaled, M.M., Ahmed, S. and Shemsi, A.M. (2011) Nano $\mathrm{ZnO}$ Synthesis by Modified Sol-Gel Method and Its Application in Heterogeneous Photocatalytic Removal of Phenol from Water. Applied Catalysis A: General, 393, 122-129. https://doi.org/10.1016/j.apcata.2010.11.032

[102] Renuka, L., Anantharaju, K.S., Vidya, Y.S., Nagaswarupa, H.P., Prashantha, S.C., et al. (2017) A Simple Combustion Method for the Synthesis of Multi-Functional $\mathrm{ZrO}_{2} / \mathrm{CuO}$ Nanocomposites: Excellent Performance as Sunlight Photocatalysts and Enhanced Latent Fingerprint Detection. Applied Catalysis B: Environmental, 210, 
97-115. https://doi.org/10.1016/j.apcatb.2017.03.055

[103] Assi, N., Mohammadi, A., Manuchehri, Q.S. and Walker, R.B. (2014) Synthesis and Characterization of ZnO Nanoparticle Synthesized by a Microwave-Assisted Combustion Method and Catalytic Activity for the Removal of Ortho-Nitrophenol. Desalination and Water Treatment, 54, 1939-1948.

[104] Chong, M.N., Jin, B., Chow, C.W.K. and Saint, C. (2010) Recent Developments in Photocatalytic Water Treatment Technology: A Review. Water Research, 44, 2997-3027. https://doi.org/10.1016/j.watres.2010.02.039

[105] Shafaei, A., Nikazar, M. and Arami, M. (2010) Photocatalytic Degradation of Terephthalic Acid Using Titania and Zinc Oxide Photocatalysts: Comparative Study. Desalination, 252, 8-16. https://doi.org/10.1016/j.desal.2009.11.008

[106] Bayarri, B., Abellán, M.N., Giménez, J. and Esplugas, S. (2007) Study of the Wavelength Effect in the Photolysis and Heterogeneous Photocatalysis. Catalysis Today, 129, 231-239. https://doi.org/10.1016/j.cattod.2007.08.006

[107] Chatzitakis, A., Berberidou, C., Paspaltsis, I., Kyriakou, G., Sklaviadis, T. and Poulios, I. (2008) Photocatalytic Degradation and Drug Activity Reduction of Chloramphenicol. Water Research, 42, 386-394.

https://doi.org/10.1016/j.watres.2007.07.030

[108] Yusoff, N., Ong, S.-A., Ho, L.-N., Wong, Y.-S. and Khalik, W.F. (2015) Degradation of Phenol through Solar-Photocatalytic Treatment by Zinc Oxide in Aqueous Solution. Desalination and Water Treatment, 54, 1621-1628.

[109] Banerjee, P., Chakrabarti, S., Maitra, S. and Dutta, B.K. (2012) Zinc Oxide Nano-Particles-Sonochemical Synthesis, Characterization and Application for Photo-Remediation of Heavy Metal. Ultrasonics Sonochemistry, 19, 85-93.

https://doi.org/10.1016/j.ultsonch.2011.05.007

[110] Neppolian, B., Wang, Q., Yamashita, H. and Choi, H. (2007) Synthesis and Characterization of $\mathrm{ZrO}_{2}-\mathrm{TiO}_{2}$ Binary Oxide Semiconductor Nanoparticles: Application and Interparticle Electron Transfer Process. Applied Catalysis A: General, 333, 264-271. https://doi.org/10.1016/j.apcata.2007.09.026

[111] Wang, F., Qin, X., Guo, Z., Meng, Y., Yang, L. and Ming, Y. (2013) Hydrothermal Synthesis of Dumbbell-Shaped ZnO Microstructures. Ceramics International, 39, 8969-8973. https://doi.org/10.1016/j.ceramint.2013.04.096

[112] Fang, Y., Li, Z., Xu, S., Han, D. and Lu, D. (2013) Optical Properties and Photocatalytic Activities of Spherical $\mathrm{ZnO}$ and Flower-Like $\mathrm{ZnO}$ Structures Synthesized by Facile Hydrothermal Method. Journal of Alloys and Compounds, 575, 359-363. https://doi.org/10.1016/j.jallcom.2013.05.183

[113] Akir, S., Barras, A., Coffinier, Y., Bououdina, M., Boukherroub, R. and Omrani, A.D. (2016) Eco-Friendly Synthesis of ZnO Nanoparticles with Different Morphologies and Their Visible Light Photocatalytic Performance for the Degradation of Rhodamine B. Ceramics International, 42, 10259-10265.

https://doi.org/10.1016/j.ceramint.2016.03.153

[114] Davar, F. and Salavati-Niasari, M. (2011) Synthesis and Characterization of Spinel-Type Zinc Aluminate Nanoparticles by a Modified Sol-Gel Method Using New Precursor. Journal of Alloys and Compounds, 509, 2487-2492. https://doi.org/10.1016/j.jallcom.2010.11.058

[115] Hong, R., Pan, T., Qian, J. and Li, H. (2006) Synthesis and Surface Modification of ZnO Nanoparticles. Chemical Engineering Journal, 119, 71-81.

https://doi.org/10.1016/j.cej.2006.03.003 
[116] Silane, T. and Acid, O. (2015) Surface Modification of ZnO Nano-Particles with Trimetoxyvinyl Silane and Oleic Acid and Studying Their Dispersion in Organic Media. International Journal of Nano Dimension, 6, 67-75.

[117] Zhao, J., Milanova, M., Warmoeskerken, M.M.C.G. and Dutschk, V. (2012) Surface Modification of $\mathrm{TiO}_{2}$ Nanoparticles with Silane Coupling Agents. Colloids and Surfaces A: Physicochemical and Engineering Aspects, 413, 273-279. https://doi.org/10.1016/j.colsurfa.2011.11.033

[118] Zhang, X., Xia, Y. and He, T. (2012) Tuning Photoluminescence Properties of ZnO Nanorods via Surface Modification. Materials Chemistry and Physics, 137, 622-627. https://doi.org/10.1016/j.matchemphys.2012.09.065

[119] Lee, K.M., Lai, C.W., Ngai, K.S. and Juan, J.C. (2016) Recent Developments of Zinc Oxide Based Photocatalyst in Water Treatment Technology: A Review. Water Research, 88, 428-448. https://doi.org/10.1016/j.watres.2015.09.045

[120] Marschall, R. (2014) Semiconductor Composites: Strategies for Enhancing Charge Carrier Separation to Improve Photocatalytic Activity. Advanced Functional Materials, 24, 2421-2440. https://doi.org/10.1002/adfm.201303214

[121] Patnaik, S., Martha, S., Acharya, S. and Parida, K.M. (2016) An Overview of the Modification of $\mathrm{g}_{-} \mathrm{C}_{3} \mathrm{~N}_{4}$ with High Carbon Containing Materials for Photocatalytic Applications. Inorganic Chemistry Frontiers, 3, 336-347.

[122] Wang, Z., Liu, Y., Huang, B., Dai, Y., Lou, Z., et al. (2014) Progress on Extending the Light Absorption Spectra of Photocatalysts. Physical Chemistry Chemical Physics, 16, 2758-2774. https://doi.org/10.1039/c3cp53817f

[123] Zhang, X., Wang, Y., Liu, B., Sang, Y. and Liu, H. (2017) Heterostructures Construction on $\mathrm{TiO}_{2}$ Nanobelts: A Powerful Tool for Building High-Performance Photocatalysts. Applied Catalysis B: Environmental, 202, 620-641. https://doi.org/10.1016/j.apcatb.2016.09.068

[124] Chang, S.J., Yang, X.Q., Sang, Y.H. and Liu, H. (2016) Highly Efficient Photocatalysts and Continuous-Flow Photocatalytic Reactors for Degradation of Organic Pollutants in Wastewater. Chemistry-An Asian Journal, 11, 2352-2371. https://doi.org/10.1002/asia.201600363

[125] Mamba, G. and Mishra, A.K. (2016) Graphitic Carbon Nitride $\left(g-\mathrm{C}_{3} \mathrm{~N}_{4}\right)$ Nanocomposites: A New and Exciting Generation of Visible Light Driven Photocatalysts for Environmental Pollution Remediation. Applied Catalysis B: Environmental, 198, 347-377. https://doi.org/10.1016/j.apcatb.2016.05.052

[126] Xu, H., Ju, J., Li, W., Zhang, J., Wang, J. and Cao, B. (2016) Superior Triethylamine-Sensing Properties Based on $\mathrm{TiO}_{2} / \mathrm{SnO}_{2} \mathrm{n}$-n Heterojunction Nanosheets Directly Grown on Ceramic Tubes. Sensors and Actuators B: Chemical, 228, 634-642. https://doi.org/10.1016/j.snb.2016.01.059

[127] Ma, L., Fan, H., Tian, H., Fang, J. and Qian, X. (2016) The $n-\mathrm{ZnO} / \mathrm{n}^{-} \mathrm{In}_{2} \mathrm{O}_{3}$ Heterojunction Formed by a Surface-Modification and Their Potential Barrier-Control in Methanal Gas Sensing. Sensors and Actuators B: Chemical, 222, 508-516. https://doi.org/10.1016/j.snb.2015.08.085

[128] Cai, A., Sun, Y., Du, L. and Wang, X. (2015) Hierarchical $\mathrm{Ag}_{2} \mathrm{O}-\mathrm{ZnO}-\mathrm{Fe}_{3} \mathrm{O}_{4}$ Composites with Enhanced Visible-Light Photocatalytic Activity. Journal of Alloys and Compounds Journal, 644, 334-340. https://doi.org/10.1016/j.jallcom.2015.03.236

[129] Shekofteh-Gohari, M. and Habibi-Yangjeh, A. (2015) Ternary $\mathrm{ZnO} / \mathrm{Ag}_{3} \mathrm{VO}_{4} / \mathrm{Fe}_{3} \mathrm{O}_{4}$ Nanocomposites: Novel Magnetically Separable Photocatalyst for Efficiently Degradation of Dye Pollutants under Visible-Light Irradiation. Solid State Sciences, 48, 
177-185. https://doi.org/10.1016/j.solidstatesciences.2015.08.010

[130] Shekofteh-Gohari, M. and Habibi-Yangjeh, A. (2015) Facile Preparation of $\mathrm{Fe}_{3} \mathrm{O}_{4} @ \mathrm{AgBr}-\mathrm{ZnO}$ Nanocomposites as Novel Magnetically Separable Visible-Light-Driven Photocatalysts. Ceramics International, 41, 1467-1476. https://doi.org/10.1016/j.ceramint.2014.09.081

[131] Shekofteh-Gohari, M. and Habibi-Yangjeh, A. (2017) $\mathrm{Fe}_{3} \mathrm{O}_{4} / \mathrm{ZnO} / \mathrm{CoWO}_{4}$ Nanocomposites: Novel Magnetically Separable Visible-Light-Driven Photocatalysts with Enhanced Activity in Degradation of Different Dye Pollutants. Ceramics International, 43, 3063-3071. https://doi.org/10.1016/j.ceramint.2016.11.115

[132] Shekofteh-Gohari, M. and Habibi-Yangjeh, A. (2015) Novel Magnetically Separable $\mathrm{Fe}_{3} \mathrm{O}_{4} @ \mathrm{ZnO} / \mathrm{AgCl}$ Nanocomposites with Highly Enhanced Photocatalytic Activities under Visible-Light Irradiation. Separation and Purification Technology, 147, 194-202. https://doi.org/10.1016/j.seppur.2015.04.034

[133] Shekofteh-Gohari, M. and Habibi-Yangjeh, A. (2016) Ultrasonic-Assisted Preparation of Novel Ternary $\mathrm{ZnO} / \mathrm{AgI} / \mathrm{Fe}_{3} \mathrm{O}_{4}$ Nanocomposites as Magnetically Separable Visible-Light-Driven Photocatalysts with Excellent Activity. Journal of Colloid and Interface Science, 461, 144-153. https://doi.org/10.1016/j.jcis.2015.09.032

[134] Habibi-Yangjeh, A. and Shekofteh-Gohari, M. (2017) Novel Magnetic $\mathrm{Fe}_{3} \mathrm{O}_{4} /$

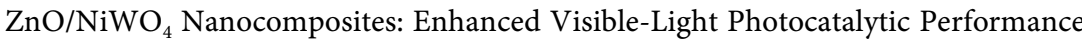
through p-n Heterojunctions. Separation and Purification Technology, 184, 334-346. https://doi.org/10.1016/j.seppur.2017.05.007

[135] Fagerlund G. (1973) Determination of Specific Surface by the BET Method. Matériaux et Construction, 6, 239-245. https://doi.org/10.1007/BF02479039

[136] Kestens, V., Roebben, G., Herrmann, J., Coleman, V., Minelli, C., Clifford, C., et al. (2016) Challenges in the Size Analysis of a Silica Nanoparticle Mixture as Candidate Certified Reference Material. Journal of Nanoparticle Research, 18, 171. https://doi.org/10.1007/s11051-016-3474-2

[137] Sikora, A., Shard, A.G. and Minelli, C. (2016) Size and $\zeta$-Potential Measurement of Silica Nanoparticles in Serum Using Tunable Resistive Pulse Sensing. Langmuir, 32, 2216-2224.

[138] Torchynska, T.V., El Filali, B., Ballardo Rodríguez, I.Ch. and Shcherbyna, L. (2016) Defect Related Emission of $\mathrm{ZnO}$ and $\mathrm{ZnO} \mathrm{Cu}$ Nanocrystals Prepared by Electrochemical Method. Physica Status Solidi C, 13, 594-597. https://doi.org/10.1002/pssc.201510277

[139] Bahadar, H., Maqbool, F., Niaz, K. and Abdollahi, M. (2016) Toxicity of Nanoparticles and an Overview of Current Experimental Models. Iranian Biomedical Journal, 20, 1-11.

[140] Khan, H.A. and Shanker, R. (2015) Toxicity of Nanomaterials. BioMed Research International, 2015, Article ID 521014. https://doi.org/10.1155/2015/521014 